\title{
Investigating patterns and controls of groundwater up-welling in a lowland river by combining Fibre-optic Distributed Temperature Sensing with observations of vertical hydraulic gradients
}

\author{
S. Krause ${ }^{1}$, T. Blume ${ }^{2}$, and N. J. Cassidy ${ }^{3}$ \\ ${ }^{1}$ School of Geographical, Earth and Environmental Sciences, University of Birmingham, Birmingham, UK \\ ${ }^{2}$ Helmholtz Centre Potsdam, GFZ German Research Centre for Geosciences, Potsdam, Germany \\ ${ }^{3}$ School of Physical and Geographical Sciences. Geography, Geology and the Environment, Keele University, Keele, UK \\ Correspondence to: S. Krause (s.krause@bham.ac.uk)
}

Received: 24 November 2011 - Published in Hydrol. Earth Syst. Sci. Discuss.: 10 January 2012

Revised: 19 May 2012 - Accepted: 22 May 2012 - Published: 29 June 2012

\begin{abstract}
This paper investigates the patterns and controls of aquifer-river exchange in a fast-flowing lowland river by the conjunctive use of streambed temperature anomalies identified with Fibre-optic Distributed Temperature Sensing (FO-DTS) and observations of vertical hydraulic gradients (VHG).

FO-DTS temperature traces along this lowland river reach reveal discrete patterns with "cold spots" indicating groundwater up-welling. In contrast to previous studies using FODTS for investigation of groundwater-surface water exchange, the fibre-optic cable in this study was buried in the streambed sediments, ensuring clear signals despite fast flow and high discharges. During the observed summer baseflow period, streambed temperatures in groundwater up-welling locations were found to be up to $1.5^{\circ} \mathrm{C}$ lower than ambient streambed temperatures. Due to the high river flows, the cold spots were sharp and distinctly localized without measurable impact on down-stream surface water temperature.

VHG patterns along the stream reach were highly variable in space, revealing strong differences even at small scales. VHG patterns alone are indicators of both, structural heterogeneity of the stream bed as well as of the spatial heterogeneity of the groundwater-surface water exchange fluxes and are thus not conclusive in their interpretation. However, in combination with the high spatial resolution FO-DTS data we were able to separate these two influences and clearly identify locations of enhanced exchange, while also obtaining information on the complex small-scale streambed transmissivity patterns responsible for the very discrete exchange
\end{abstract}

patterns. The validation of the combined VHG and FO-DTS approach provides an effective strategy for analysing drivers and controls of groundwater-surface water exchange, with implications for the quantification of biogeochemical cycling and contaminant transport at aquifer-river interfaces.

\section{Introduction}

1.1 Motivation: the importance of groundwatersurface water exchange at aquifer-river interfaces

Hydrological sciences have experienced a significant paradigm shift in recent years, advancing the rather static perception of rivers and aquifers as discrete entities towards a more complex and dynamic understanding of groundwater and surface water as integral components of a streamcatchment continuum (Bencala, 1993; Brunke and Gonser, 1997; Boulton et al., 1998; Boulton, 2007; Sophocleous, 2002; Krause et al., 2009a, 2011a; Woessner, 2000). The hyporheic zone (HZ), i.e. the interface between aquifer and river, plays a major role with respect to river ecohydrology and hydrochemistry. (e.g. Malcolm et al., 2002, 2004; Stubbington et al., 2009; Robertson and Wood, 2010; DoleOlivier et al., 1997; Malard et al., 2003; Fisher et al., 1998; Mulholland et al., 2000, 2008; Pinay et al., 2009; Krause et al., 2009b).

Reaction efficiency in hyporheic sediments is controlled by (i) the existence of steep redox-gradients and the availability of organic matter and microbial activity (Chafiq et 
al., 1999; Storey et al., 2004; Duff and Triska, 1990; Hinkle et al., 2001; Jones et al., 1995; Findlay et al., 1993, 2003; Fisher et al., 1998; Hill and Cardaci, 2004; Zarnetzke et al., 2011a) as well as (ii) hyporheic flow paths and residence times (Zarnetzke et al., 2011b; Fisher et al., 1998; Bencala et al., 1993; Duff and Triska, 2000; Jones et al., 1995). Hence, a detailed understanding of groundwater-surface water exchange flow patterns is essential for the quantitative assessment of biogeochemical cycling at aquifer-river interfaces (White, 1993; Krause et al., 2011a).

A better understanding of streambed controls on patterns of groundwater-surface water exchange and residence times at aquifer-river interfaces is particularly critical in lowland river systems where nutrient loads in groundwater and surface water are often increased as result of intensified agricultural management practice. The potential for hyporheic and riparian nutrient attenuation in lowland rivers has been shown to be substantial (Krause et al., 2008a, b; Pinay et al., 2009; Zarnetske et al., 2011b). However, as result of the depositional history of the river system, exchange flow between groundwater and surface water can be spatially highly heterogeneous, causing complex flow patterns at the aquifer-river interface (Fleckenstein et al., 2006; Lowry et al., 2007; Rosenberry and Pitlick, 2009). Uncertainty in the detection of exchange flow patterns increases with increasing spatial scale (White, 1993; Kasahara and Wondzel, 2003; Krause et al., 2009a, 2011a), with crucial implications for the (un)certainty of predictions of HZ biogeochemical and ecohydrological functioning (Brunke and Gonser, 1997; Boulton et al., 1998; Krause et al., 2011c).

Exchange fluxes over the aquifer-river interface are controlled (i) by hydraulic head gradients between groundwater and surface water as driving force and (ii) by the hydraulic conductivity of streambed sediments, which controls and limits the exchange. At the larger (up to several kilometre) stream reach to sub-catchment scale, exchange fluxes between groundwater and surface water can be strongly affected by larger geological heterogeneities in the alluvial aquifer and the resulting groundwater flow field (Cardenas and Wilson, 2006; Fleckenstein et al., 2006; Engdahl et al., 2010; Frei et al., 2009). At smaller, plot to stream reach scales, however, exchange fluxes over the aquifer-river interface appear to be strongly controlled by spatial patterns of streambed hydraulic conductivity (Genereux et al., 2008; Leek et al., 2009; Calver, 2001; Rosenberry, 2008; Käser et al., 2009) and streambed topography (Storey et al., 2003; Boano et al., 2006, 2010; Cardenas, 2009; Cardenas et al., 2008; Kasahara and Hill, 2008; Tonina and Buffington, 2007).

Although groundwater-surface water exchange fluxes have been subject to intensive investigation in the last two decades (e.g. Bencala, 1993; Cardenas et al., 2004; Cardenas and Wilson, 2006; Conant, 2004; Wondzell, 2006; Kasahara and Wondzell, 2003) the identification of spatial patterns and temporal dynamics of exchange fluxes between groundwater and surface water remains a challenge (White, 1993; Krause et al., 2011a).

As direct field measurements of groundwater-surface water exchange for instance by seepage meters (Rosenberry et al., 2008) are difficult, in particular in coarser streambed sediments (Rosenberry and Pitlick, 2009), vertical hydraulic gradients (VHGs) obtained from head observations in streambed piezometers have been widely used to describe the direction and magnitude of GW-SW fluxes (e.g. Krause et al., 2009b; Conant, 2004).

\subsection{Heat as tracer for exchange fluxes at the aquifer-river interface}

Several studies have demonstrated that temperature may be an efficient tracer for inferring groundwater-surface water interactions (e.g. Schmidt et al., 2007; Anibas et al., 2009; Hannah et al., 2004, 2009; Constantz et al., 2003; Cardenas and Wilson, 2007; Krause et al., 2011b).

Streambed heat transfer is controlled by three processes: (i) advective heat transfer, (ii) conductive heat transfer, and (iii) radiative heat transfer (Constantz, 2008; Hannah et al., 2004; Webb et al., 2008). Streambed temperature patterns have been frequently reported to be dominantly controlled by advective heat fluxes from down-welling surface waters or up-welling groundwater (Cardenas and Wilson, 2007; Hannah et al., 2004; Malcolm et al., 2002). By measuring streambed temperatures in an environment with significant differences in groundwater and surface water temperatures, the propagation of a heat signal can be used as proxy, indicating exchange flow directions (Hatch et al., 2010; Keery et al., 2007; Anibas et al., 2009; Schmidt et al., 2007; Anderson, 2005) or even to quantify exchange fluxes (Hatch et al., 2010; Westhoff et al., 2007).

The great advantages of temperature tracing methods are the relatively low costs and robust design of sensor technology. In particular the recent introduction of Fibre-optic Distributed Temperature Sensor (FO-DTS) networks into hydrology (Selker et al., 2006a, b; Selker, 2008; Tyler et al., 2009) has helped to significantly increase the spatial and temporal scale of temperature observations.

With one exception (Lowry et al., 2007) previous FO-DTS applications usually deployed the fibre-optic cable directly on top of the streambed surface (Selker et al., 2006 a, b; Tyler et al., 2009; Westhoff et al., 2007; Slater et al., 2010). Therefore, temperatures measured along the fibre-optic cable did not directly reflect streambed pore-water temperatures but temperatures at the bottom of the surface water column. A majority of previous FO-DTS studies for the identification of aquifer-river exchange fluxes focused on smaller headwater streams. Relative groundwater contributions in these environments were large enough to cause measurable changes in temperatures at the bottom of the surface water column (e.g. Selker et al., 2006; Westhoff et al., 2007), often causing a change in stream temperature even down-stream of the 
groundwater input. The resulting stream temperature traces along the length of the river resemble step functions, instead of showing single localized spikes at locations of groundwater entering the stream. FO-DTS applications for identification of groundwater-surface water exchange flow patterns in lowland settings and larger streams, where relative groundwater contributions are smaller and therefore less likely to cause measurable changes in surface water temperatures, are limited in number (Lowry et al., 2007; Hoes et al., 2009; Slater et al., 2010).

\subsection{Aims and objectives}

The applicability of VHG observations for predicting groundwater-surface water exchange flow patterns is limited as VHGs indicate pressure distributions only and a quantification of fluxes would require additional consideration of sediment hydraulic conductivities (Käser et al., 2009). This fact presents a particular challenge in lowland rivers with complex patterns and wide ranges of streambed hydraulic conductivities. Furthermore, the VHG signal provides information on both, forces and controls of aquifer-river exchange that are hard to discriminate. High VHG for instance can be caused by (i) regionally strong groundwater upwelling or (ii) local up-welling inhibition by streambed sediments of low hydraulic conductivity above the piezometer screen section.

FO-DTS monitored streambed temperatures on the other hand can provide a powerful indicator for patterns in groundwater-surface water exchange, in particular when a buried fibre-optic cable allows the direct measurement of streambed temperatures (Lowry et al., 2007). Although observed streambed temperature anomalies may be used to identify aquifer-river exchange flow patterns, they do not provide any information on the controls of the observed exchange flow patterns.

The objective of this study is to analyze the suitability of comparative analyses of FO-DTS derived temperature observations and piezometer VHG observations for identifying spatial patterns and temporal dynamics of aquifer-river exchange fluxes at an exemplary lowland river. We therefore aim to (i) identify actual exchange flow patterns at the aquifer-river interface, (ii) combine FO-DTS and VHG observations within a methodological framework that supports the analysis of process inference (specifically drivers and controls of aquifer-river exchange) and (iii) test the validity of framework inferred controls by comparison with streambed structural information

\section{Materials and methods}

\subsection{Study area}

The study focuses on an approximately $300 \mathrm{~m}$ long meandering stream section of the River Tern $\left(2^{\circ} 53^{\prime} \mathrm{W}, 52^{\circ} 86^{\prime} \mathrm{N}\right)$
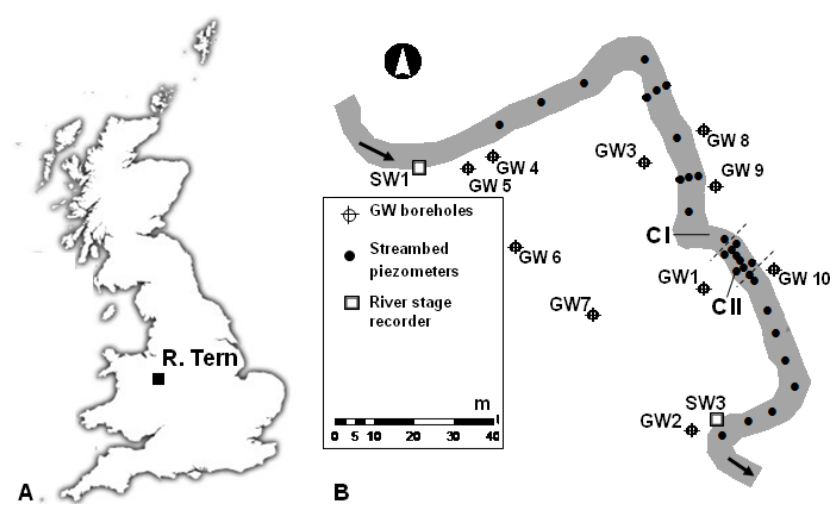

Fig. 1. (A): field site location in the UK and (B): experimental design at the River Tern with groundwater boreholes (GW), surface water gauges (SW) and the streambed piezometer network. The locations of exemplary sediment cores $\mathrm{CI}$ and $\mathrm{CII}$ are indicated in close vicinity to the pronounced pool-riffle-pool area, investigated by Krause et al. (2011b) (indicated by hatched lines).

(Fig. 1a). The field site extends into the immediate floodplain on both sides of the river (Fig. 1b). The wider research area was the subject of previous intensive investigations. It was selected by the UK Natural Environment Research Council (NERC) to represent characteristic lowland conditions within the Lowland Catchment Research Programme (LOCAR; Wheater and Peach, 2004). The local geology is dominated by the Permo-Triassic Sherwood Sandstone (PTS) formation, which forms one of the UK's major groundwater aquifers. The PTS is overlain by drift deposits of variable depth and hydraulic conductivities. Land use in the research area is dominated by pasture. The mean annual precipitation at the field site is $583 \mathrm{~mm}$. Mean daily air temperature ranges from $3.7^{\circ} \mathrm{C}$ (January) to $15.8^{\circ} \mathrm{C}$ (July), with long-term (1957-2007) mean annual temperatures of $9.3^{\circ} \mathrm{C}$ (Hannah et al., 2009). Mean river discharge at the Environment Agency operated Tern Hill $\left(2^{\circ} 55^{\prime} 12^{\prime \prime} \mathrm{W}, 52^{\circ} 87^{\prime} 92^{\prime \prime} \mathrm{N}\right)$ gauging station (basin area $92 \mathrm{~km}^{2}$, elevation $62 \mathrm{~m}$ a.s.l.) is $0.9 \mathrm{~m}^{3} \mathrm{~s}^{-1}$ with a $95 \%$ exceedance $\left(Q_{95}\right)$ of $0.4 \mathrm{~m}^{3} \mathrm{~s}^{-1}$ and a $10 \%$ exceedance $\left(Q_{10}\right)$ of $13.9 \mathrm{~m}^{3} \mathrm{~s}^{-1}$ (data period $1971-$ 2010, UK National River Flow Archive, http://www.ceh. ac.uk/data/nrfa/data/time_series.html?54044). Summer baseflow conditions usually occur from May to October. The 5$8 \mathrm{~m}$ wide channel is limited by steep, on average $2 \mathrm{~m}$ high river banks and includes a succession of pool-riffle-pool sequences mainly in the middle of the study reach (Krause et al., 2011b).

Cores taken from the streambed (Fig. 1b) revealed substantial spatial sediment heterogeneity. Figure 2 shows two example streambed cores that are representative for the sediment conditions in the investigated stream section. Streambed sediments generally varied from mid-sized gravels to fine silty material with hydraulic conductivities (identified based on grain size distributions) typically in the range 
A
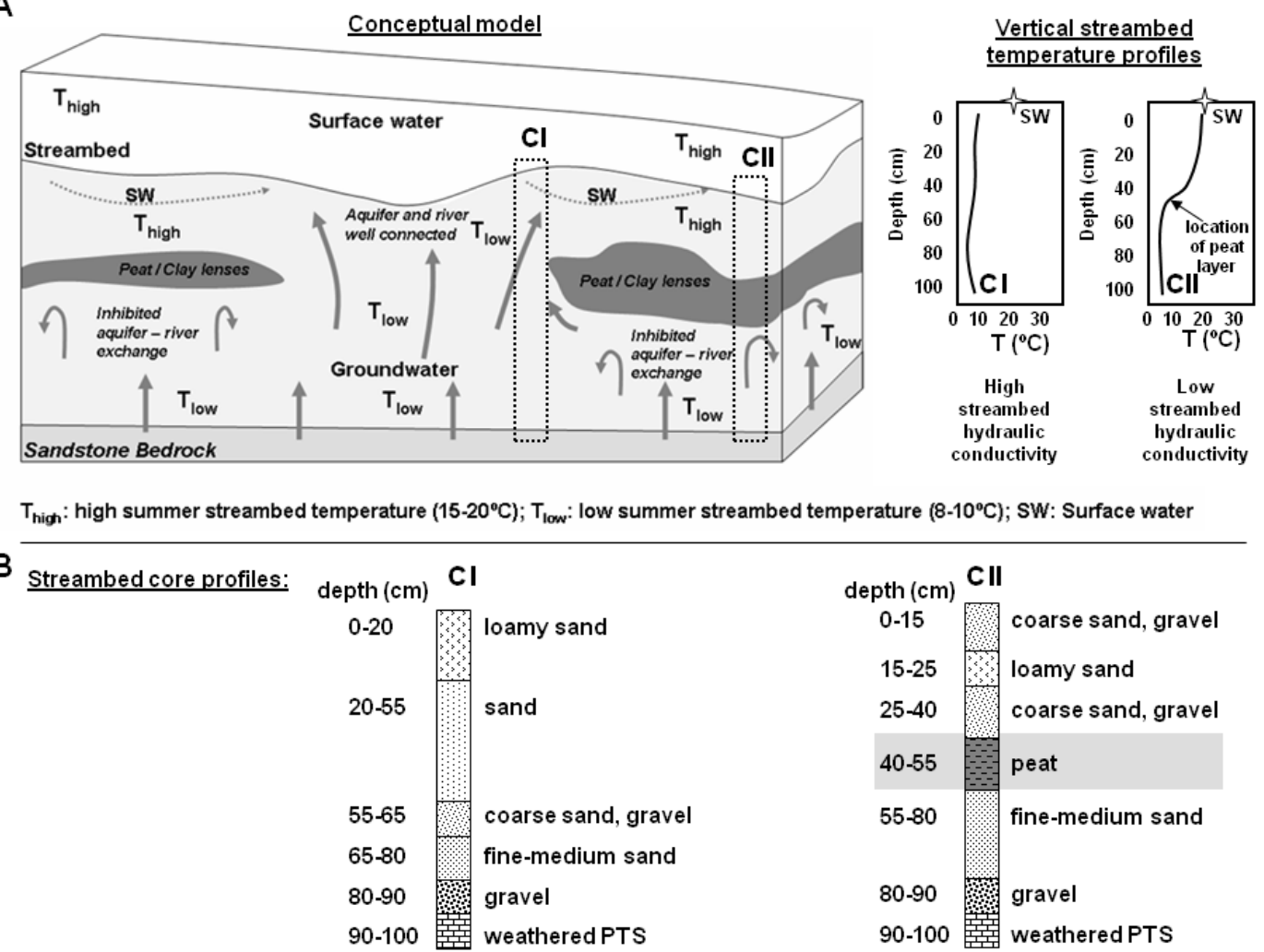

Fig. 2. (A): conceptual model of streambed hydrofacies controlling groundwater up-welling in a typical lowland river including their effect on heat transport at the aquifer-river interface (the star indicates the temperature of the surface water). (B): core logs of example streambed cores $\mathrm{CI}$ and $\mathrm{CII}$ (for sampling locations see Fig. 1).

of $10^{-3}-10^{-5} \mathrm{~m} \mathrm{~s}^{-1}$ (as represented by core CI, Fig. 2). The hydraulically most significant difference in streambed material was represented by the existence or absence of clay and peat layers of generally lower hydraulic conductivity $\left(10^{-8}\right.$ $10^{-9} \mathrm{~m} \mathrm{~s}^{-1}$ ) as indicated in core CII (Fig. 2). The thickness and depth of the peat or clay structures within 15 cores of the streambed and riparian floodplain varied but did not exceed a thickness of $30 \mathrm{~cm}$. During piezometer installation, no peat or clay structures were found below streambed depths of $120 \mathrm{~cm}$. Streambed peat or clay structures are common in lowland rivers (Krause et al., 2007). With hydraulic conductivities in the range of $10^{-8} \mathrm{~m} \mathrm{~s}^{-1}$, flow through these sediments is significantly reduced, potentially causing flow confinement and increased streambed residence times for upwelling groundwater (Fig. 2a).

\subsection{Experimental infrastructure}

Field data comprising temperature measurements of groundwater, surface water, interstitial pore-water and air, as well as hydraulic head measurements in groundwater, surface water and streambed interstitial pore-water were collected between May and September 2009 (Table 1). Meteorological data were recorded at the nearby Keele meteorological sta- tion $\left(52^{\circ} 59^{\prime} 55.86^{\prime \prime} \mathrm{N} ; 2^{\circ} 16^{\prime} 12.90^{\prime \prime} \mathrm{W}\right)$. For observation of the shallow riparian groundwater within the floodplain drift deposits, ten $3 \mathrm{~m}$ deep groundwater boreholes were installed at the field site in 2008 (Fig. 1b). Three of the groundwater boreholes (GW1, GW3, GW7, Fig. 1b) and two river-stage gauging stations (SW1, SW3, Fig. 1b) were instrumented with pressure transducers to monitor both, surface water and groundwater head (i.e. water depth) at 5-15 min intervals (Table 1). Monitored groundwater and surface water pressure heads were corrected for barometric pressure fluctuations using an atmospheric pressure sensor located at groundwater borehole site GW 7 (Fig. 1b). Differential GPS was used for measuring the exact elevations of the installed boreholes and piezometers.

PTFE (polytetrafluoroethylene) streambed piezometers comprising a central tube $(12 \mathrm{~mm}$ inner diameter with a $10 \mathrm{~cm}$ long bottom screening section) for observations of interstitial pore-water heads and up to seven tubes $(1 \mathrm{~mm}$ inner diameter) for sampling of pore-water profiles (Fig. 3a) were installed to depths of $150 \mathrm{~cm}$ within the streambed in 2008 (Figs. 1b, 3a). This setup allows for the investigation of aquifer-river exchange flow but does not account for very superficial (top $\mathrm{cm}$ ) near-surface exchange fluxes. In this study, the failure of pore-water extraction from the 

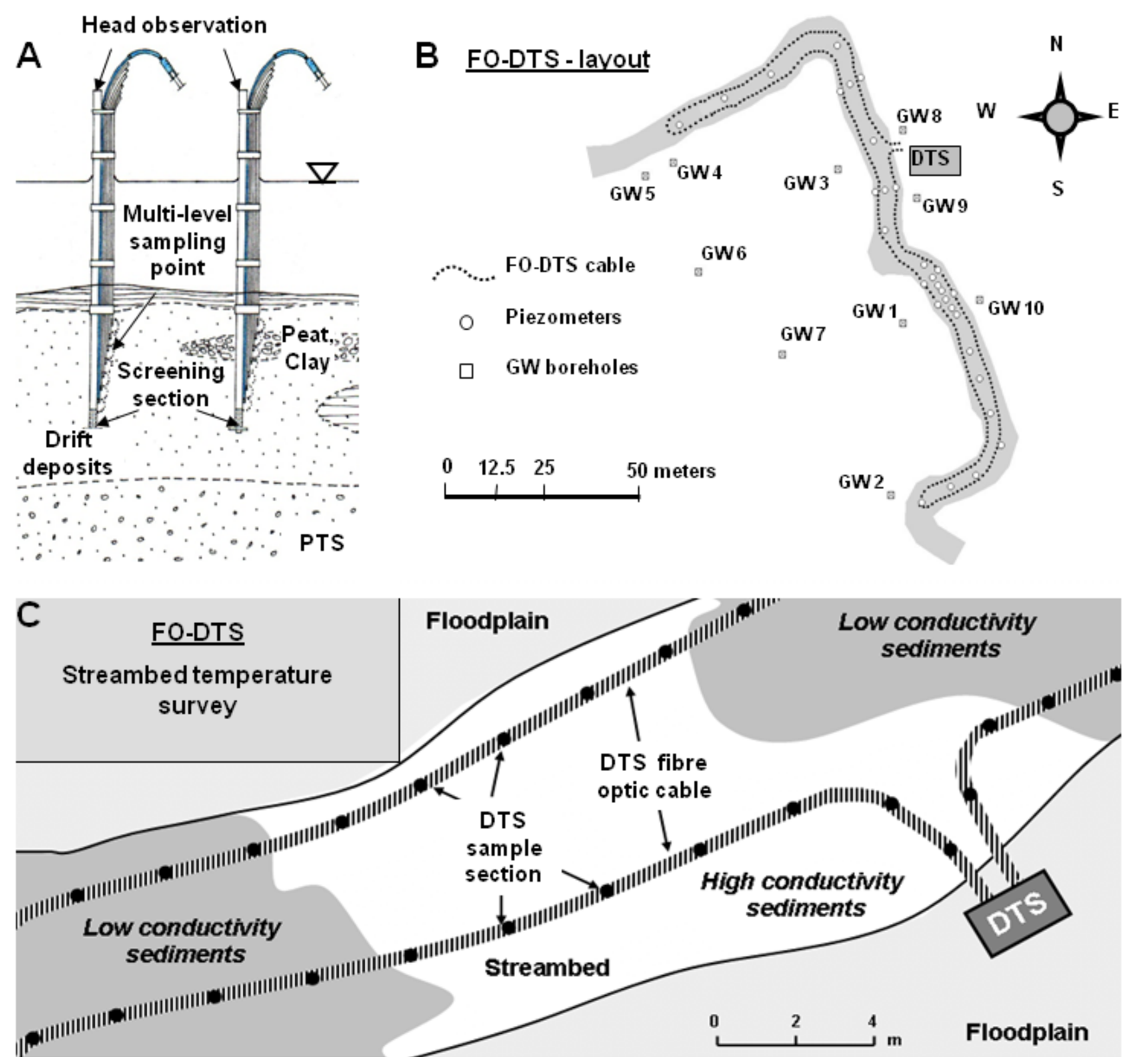

Fig. 3. Experimental installations at the River Tern with (A): streambed piezometer setup for VHG monitoring, PTS = Permo-Triassic Sandstone.; (B): FO-DTS cable loop in the investigated meander bend; (C): close-up of cable layout in the streambed sediment with measurement intervals indicated by the DTS sample sections. (The outline of the low-conductivity sediments is hypothetical).

$1 \mathrm{~mm}$ diameter multi-level tubes has been used as indicator of low permeability peat or clay strata at the respective depths as streambed coring and core extraction were limited in order to minimize the disturbance of the investigated insitu streambed conditions. The piezometers were set up in a longitudinal transect along the stream reach with several cross-sectional extensions towards the river banks (Fig. 1). Hydraulic heads in streambed piezometers were monitored manually on seven sampling dates between 21 May 2009 and 30 September 2009 (Table 1), using an electric contact meter (dip-meter). Manual dip-meter measurements also covered the network of shallow riparian groundwater boreholes to provide quality assurance for the automatically logged pressure heads.

A fibre-optic Distributed Temperature Sensor network was employed for investigation of the streambed temperature patterns in response to aquifer-river exchange fluxes. FODTS uses the temperature dependent backscatter properties of a laser signal that propagates through a fibre-optic cable (Selker et al., 2006a, b; Tyler et al., 2009). The FO-
DTS method applied in this project uses the offset in the backscatter of Raman stokes and anti-stokes signals from a 10 nanosecond light pulse to undertake and locate temperature measurements along the fibre-optic cable (Selker et al., 2006a, b). The applied FO-DTS system (Sensornet Halo, Table 1) is capable of measuring temperature at high precision $\left(0.05^{\circ} \mathrm{C}\right.$ for $30 \mathrm{~s}$ intervals $)$ and with a spatial resolution of $2 \mathrm{~m}$ (Sensornet, 2009).

For the temperature survey, a metal-armored two channel fibre-optic cable (BruSteel, Brugg/CH) was deployed. In most FO-DTS studies (except Lowry et al., 2007), the cable has been deployed on the streambed, resulting in measurements of temperature at the bottom of the surface water column. In contrast, in this study the fibre-optic cable was installed at an average depth of $5 \mathrm{~cm}$ within the streambed in order to directly measure streambed temperature and avoid signal loss due to advective lateral heat transport at the streambed surface caused by river flow. By ensuring careful installation of the cable along a longitudinal succession of shallow cuts into the streambed, variations in the depth 
Table 1. Spatial and temporal resolution of environmental parameters monitored during the 2009 sampling period.

\begin{tabular}{|c|c|c|c|}
\hline Environmental variable & Observation interval & Instrumentation & Accuracy \\
\hline $\begin{array}{l}\text { Temperature - SW } \\
\text { Temperature - GW }\end{array}$ & $\begin{array}{l}5 \mathrm{~min} \\
15 \mathrm{~min}\end{array}$ & $\begin{array}{l}\text { Solinst LT M5/F15 diver, com- } \\
\text { bined level and temperature } \\
\text { logger }\end{array}$ & $\begin{array}{l} \pm 0.05^{\circ} \mathrm{C} \\
\pm 0.05^{\circ} \mathrm{C}\end{array}$ \\
\hline Temperature - HZ & $15 \mathrm{~min}$ & $\begin{array}{l}\text { Hobo - 4-channel temperature } \\
\text { logger and thermocouple } \\
\text { sensors }\end{array}$ & $\pm 0.025^{\circ} \mathrm{C}$ \\
\hline Temperature - Air & $1 \mathrm{~h}$ & Keele, meteorological station & $\pm 0.05^{\circ} \mathrm{C}$ \\
\hline $\begin{array}{l}\text { Hydraulic head - } \\
\text { SW/Hydraulic head - } \\
\text { GW/Barometric head }\end{array}$ & $5 \mathrm{~min} / 15 \mathrm{~min} / 5 \mathrm{~min}$ & $\begin{array}{l}\text { Solinst LT M5/F15 diver, com- } \\
\text { bined water level and tempera- } \\
\text { ture logger/Solinst } \\
\text { BaroLogger }\end{array}$ & $\pm 0.3 \mathrm{~cm}$ \\
\hline $\begin{array}{l}\text { Hydraulic head } \\
\text { streambed surveys } 2009 \\
\text { Precipitation }\end{array}$ & $\begin{array}{l}21 \text { May, } 2 \text { June, } 19 \text { June, } \\
30 \text { June, } 31 \text { July, } 21 \text { August, } \\
\text { 30 Septembe } 1 \mathrm{~h}\end{array}$ & $\begin{array}{l}\text { Streambed piezometer and } \\
\text { graduated dip-meter Keele, } \\
\text { meteorological station (18 km } \\
\text { distance) }\end{array}$ & $\begin{array}{l} \pm 0.3 \mathrm{~cm} \\
\pm 0.2 \mathrm{~mm}\end{array}$ \\
\hline Discharge $(Q)$ & $1 \mathrm{~h}$ & EA gauging station Tern Hill & $\pm 5 \%$ \\
\hline $\begin{array}{l}\text { DTS streambed } \\
\text { temperature surveys } 2009\end{array}$ & $\begin{array}{l}23 \text { July, } 03 \text { August, } 06 \text { Au- } \\
\text { gust, } 18 \text { August, } 19 \text { August } \\
\text { (night), } 19 \text { August (day) }\end{array}$ & FO-DTS (Sensornet Halo) & $\pm 0.05^{\circ} \mathrm{C}$ \\
\hline
\end{tabular}

of the deployed cable were assumed to be less than $\pm 2.5 \mathrm{~cm}$ and disturbance of the streambed sediments was minimized. The cable was secured by approximately 100 tent pegs attached to the fibre-optic cable with plastic cable ties to avoid preferential heat conduction along the metal pegs. Regular visual inspections of the buried cable prevented any cable exposure during the monitoring period. Introduced temperature variability as a result of spatially variable heat conduction and topography induced shallow hyporheic exchange into the sediment is small, according to previous investigations in the research area, with a maximum of $0.2-0.3^{\circ} \mathrm{C}$ (Krause et al., 2011b). To match the spatial extent of the streambed VHG observations along the streambed piezometer network, the fibre-optic cable was deployed along a $500 \mathrm{~m}$ loop, covering both sides of the streambed (Fig. 3). Measurements were taken in double-ended mode, whereby both ends of the fibre-optic cable were connected to the instrument and measurements with alternating directions were averaged over $10 \mathrm{~s}$ intervals. For the FO-DTS streambed temperature surveys, carried out during six observation days between 23 July 2009-19 August 2009 (Table 1), at least 100 double-ended measurements were averaged for each survey.

In order to calculate temperature offset and losses along the cable, sections of both cable ends were calibrated in temperature controlled warm and cold baths, allowing for a dynamic FO-DTS calibration. For the identification and moni- toring of background temperatures in groundwater and surface water, thermistors integrated in the water level pressure transducers measured temperatures at 5 to $15 \mathrm{~min}$ intervals (Fig. 1, Table 1). Additionally, reference measurements of streambed temperature were carried out at 15-min intervals by streambed thermistors installed at 5 and $10 \mathrm{~cm}$ depths along a pool-riffle pool succession at section P13-22 (Fig. 6, Krause et al., 2011b).

The combination of FO-DTS-derived streambed temperatures and VHG observations at streambed piezometers was used to provide a framework of case-distinctions of groundwater - surface water exchange fluxes in response to variability in streambed hydraulic conductivity, in particular caused by the presence or absence of flow-confining streambed strata. A complete physical characterization of the highly heterogeneous streambed sediments for validation of presence or absence of low conductive streambed strata would have not been possible without complete disturbance of the in-situ sampling conditions. Therefore, assumptions regarding the presence of flow confining strata at piezometer locations were validated by analysing the sampling behavior of the mini-sampling tubes installed at approximately $20 \mathrm{~cm}$ intervals along the length of the piezometers. 


\subsection{Data analysis}

VHG, indicating the strength and direction of exchange fluxes between groundwater and surface water, were determined from hydraulic head measurements in the streambed. VHG were calculated by $\Delta h / \Delta l$, with $\Delta h$ given by the elevation difference of the water table observed inside and the stream stage outside the piezometer and $\Delta l$ given by the distance between the mid-screen depth and the surface water - sediment interface. The accuracy of dip-meter based hydraulic head observations was approximately $\pm 3 \mathrm{~mm}$ head and accounts for uncertainties in the measurements introduced by turbulent flow conditions around the piezometers, which can affect the outside head estimates (Krause et al., 2009b; Käser et al., 2009).

The analysis of the FO-DTS data focused on the determination of temperature anomalies along the trace of the cable. Using the difference of a local temperature measurement to the spatial average temperature of the cable section within the streambed at a specific point in time as an indicator of the strength of the temperature anomaly $\left(A_{\mathrm{T}}\right)$, allows to compare anomalies on different dates independent of general (global) shifts in sediment temperatures and thus, provides a measure of the temporal variability of these signals (Eq. 1).

$A_{\mathrm{T}}\left(X_{i}\right)=T\left(X_{i}\right)-\overline{(T(x))}$

$x_{i}=$ measurement location along the cable; all units in $\left[{ }^{\circ} \mathrm{C}\right]$.

As this study focuses on a strongly gaining lowland river during summer, when groundwater temperatures are lower than surface water and mainly negative temperature anomalies have to be expected as a result of cold groundwater inputs. Anomaly strength is expected to vary with (i) changes in groundwater up-welling and (ii) variation in temperature differences between groundwater and surface water.

A similar analysis was carried out for the vertical hydraulic gradients, compensating for overall (global) shifts in hydraulic gradients and thus, allowing for quantification and comparison of the strength of $\mathrm{VHG}$ anomalies $\left(A_{\mathrm{VHG}}\right)$ (Eq. 2).

$A_{\mathrm{VHG}}\left(X_{i}\right)=\operatorname{VHG}\left(X_{i}\right)-\overline{(\operatorname{VHG}(X))}$

$x_{i}=$ location of the piezometer, all units $[-]$.

The variability of temperature and $V H G$ anomalies $A_{\mathrm{T}}$ $\left(x_{i}\right)$ and $A_{\mathrm{VHG}}\left(x_{i}\right)$ is described by their temporal standard deviation (STDEV) (Eqs. 3 and 4):

$\operatorname{STDEV}\left(A_{\mathrm{T}}\left(X_{i}\right)\right)=\sqrt{\frac{1}{N} \sum_{t=1}^{N}\left(A_{\mathrm{T}}\left(X_{i t}\right)-\overline{A_{\mathrm{T}}\left(X_{i}\right)}\right)^{2}}$

$\operatorname{STDEV}\left(A_{\mathrm{VHG}}\left(X_{i}\right)\right)=\sqrt{\frac{1}{N} \sum_{t=1}^{N}\left(A_{\mathrm{VHG}}\left(X_{i t}\right)-\overline{A_{\mathrm{VHG}}\left(X_{i}\right)}\right)^{2}}$

$x_{i t}=$ measurement location at the time $t$.

\section{Results}

\subsection{Hydroclimatological conditions}

Air temperatures varied by more than $20^{\circ} \mathrm{C}$ during the observation period with $T_{\max }=26.3^{\circ} \mathrm{C}, T_{\min }=5.6^{\circ} \mathrm{C}$ and an average of $15.2^{\circ} \mathrm{C}$ (Fig. 4a). Diurnal air temperature amplitudes varied substantially with maximum day-night temperature differences of up to $14{ }^{\circ} \mathrm{C}$ in June and July. Although generally low in precipitation, the observation period included an extended wet period during July and early August (Fig. 4b). The summer baseflow period, with daily discharge ranging between $0.7-0.8 \mathrm{~m}^{3} \mathrm{~s}^{-1}$, was interrupted by a major discharge event with $Q>1.5 \mathrm{~m}^{3} \mathrm{~s}^{-1}$ and $>20$ days with discharges $>1.0 \mathrm{~m}^{3} \mathrm{~s}^{-1}$ resulting from the prolonged wet conditions in July 2009. Although the runoff regime is mainly groundwater driven, a couple of rainfall events caused very immediate reactions in river discharge (e.g. during early June - see Fig. 4b). The fibre-optic cable was installed during 30-31 June 2009. Stream discharge after the end of July peak flow event receded quickly in August 2009. Visual inspections of the buried fibre-optic cable did not reveal any significant sediment shift during the FO-DTS survey.

\subsection{Riparian groundwater-surface water head patterns}

Water levels at representative riparian groundwater boreholes (GW1, GW3, GW7) and river gauges (SW3) (see Fig. 1) were generally low during the baseflow conditions, interrupted only by a three-week episode of increased groundwater and surface water levels in July 2009 (Fig. 5a), which was caused by the precipitation events (Fig. 4a). Throughout most of the monitoring period, water levels in the groundwater boreholes (Fig. 1) exceeded surface water levels, indicating a general flow direction towards the stream. Inverse head gradients (indicating reversed flow conditions) were only observed during storm events (Fig. 4) when surface water levels rose faster and higher than the associated groundwater levels (Fig. 5a), causing surface water infiltration into the riparian groundwater.

\subsection{Groundwater and surface water temperature patterns}

Surface water temperature varied by more than $10^{\circ} \mathrm{C}$ with $T_{\min }=11.7^{\circ} \mathrm{C}$ and $T_{\max }=22.2^{\circ} \mathrm{C}$, whilst the range of temperature variations observed in the four groundwater boreholes (including also GW2, Figs. 1, 5b) during the monitoring period was lower, i.e. $3.7^{\circ} \mathrm{C}\left(T_{\min }=9.4^{\circ} \mathrm{C}\right.$, $T_{\max }=13.1^{\circ} \mathrm{C}$ ). The temporal dynamics of the stream temperatures (Fig. 5b) strongly followed air temperature patterns (Fig. 4a), with maximums in June and July. In contrast, groundwater temperatures increased towards $\mathrm{Au}-$ gust and September, indicating a time lag of at least several-weeks in response to surface water and atmospheric conditions (Figs. 4a, 5b). 
A
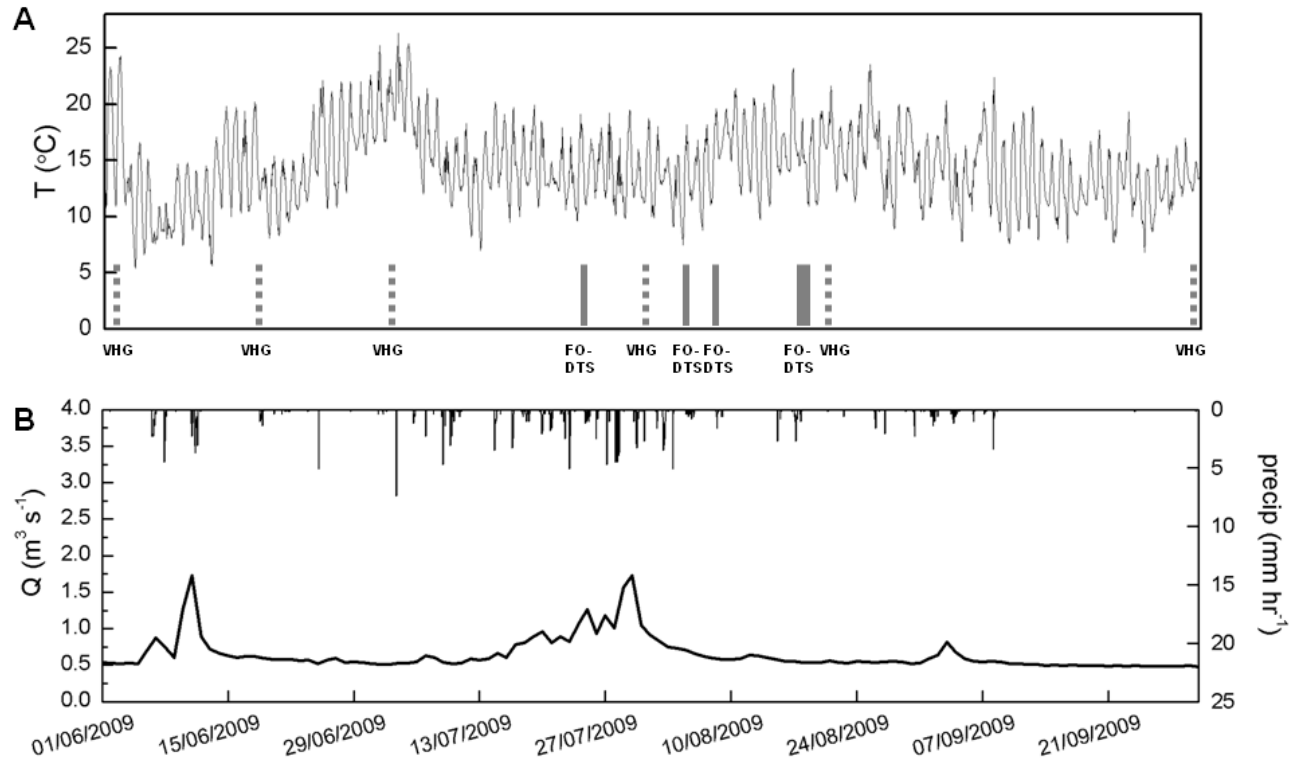

Fig. 4. Hydrometeorological conditions at the fieldsite (A): air temperatures, (B): precipitation and river discharge (EA Tern Hill gauging station) for the period of 1 June 2009-30 September 2009. Dotted and solid bars in (A) indicate timing of the VHG and FO-DTS surveys.

The described temperature patterns produce strong thermal differences between the groundwater and surface water (Fig. 5b). From June to August, surface water temperatures were up to $9.0^{\circ} \mathrm{C}$ (average $3.1^{\circ} \mathrm{C}$ ) higher than groundwater temperatures. Towards the end of the observation period in September, differences between the groundwater and surface water temperatures became less distinct. During this period, the direction of groundwater-surface water temperature differences changed on several occasions (Fig. 5b).

Diurnal temperature amplitudes in the surface water were similarly pronounced with ranges of up to $2.4{ }^{\circ} \mathrm{C}$ in June and July, but decreasing to below $1.0^{\circ} \mathrm{C}$ in September (Fig. 5b). In contrast, groundwater temperatures exhibited no clear diurnal periodicity. Maximum daily changes in groundwater temperatures were below $0.2^{\circ} \mathrm{C}$. Even taking into account the up to $2.4^{\circ} \mathrm{C}$ diurnal surface water temperature amplitudes, up to the end of August, thermal differences between groundwater and surface water frequently exceeded $5{ }^{\circ} \mathrm{C}$ during the day time.

\subsection{Spatial patterns of vertical hydraulic gradients and FO-DTS temperatures}

VHG at the 28 streambed piezometers were positive throughout the monitoring period (7 sampling dates during summer 2009), indicating groundwater up-welling into the river (Fig. 6). Observed VHG were spatially variable with values ranging from 0 (indicating hydraulic heads at the piezometer equal to the hydrostatic pressure of the stream and no upor down-welling) to 0.92 . Figure 6 shows the VHG averaged over the entire monitoring period. At the most up-stream and down-stream sections in the North (P1-3) and the South end
(P25-27) of the meander, average VHG were low to moderate with $0.20-0.30$ (average 0.26 ) whilst the NorthwestSoutheast oriented central part (P4-24) of the meander section was characterised by higher VHG ranges. Although spatial averages of VHG were quite similar in both sections $(\mathrm{P} 4-12=0.30$ and $\mathrm{P} 13-24=0.32)$, the spatial variation of observed VHG over the more down-stream section P13-24 exceeded with a range of $0.03-0.57$ the observed range of VHG over the more up-stream section P4-12 (0.19-0.47).

Fibre-optic Distributed Temperature surveys were carried out on six occasions in July and August 2009 (Table 1). Figure 7 shows the temperature data mapped onto the river reach (4 temperature traces averaged over $20 \mathrm{~s}$ on different dates). Distinctive cold spots with streambed temperatures of up to $2^{\circ} \mathrm{C}$ below the spatial average were found close to both ends (P1-4, P25-27) of the investigated reach as well as around piezometer locations P8 and P12 (compare Fig. 6). Although the range of streambed temperature variation was larger for the first two observation dates (3 August 2009, 6 August 2009), the location and spatial extent of the observed cold spots remained stable throughout the FO-DTSmonitoring dates (Fig. 7).

\subsection{Temporal dynamics of spatial patterns (signal stability)}

While VHG and FO-DTS temperatures showed distinct spatial patterns for each snapshot sampling, hydraulic gradients and temperatures at each sampling point also exhibited considerable temporal variability. To investigate the temporal stability of the overall spatial patterns we analysed the strength and persistence of "anomalies" $A_{\mathrm{T}}\left(x_{i}\right)$ and $A_{\mathrm{VHG}}$ 

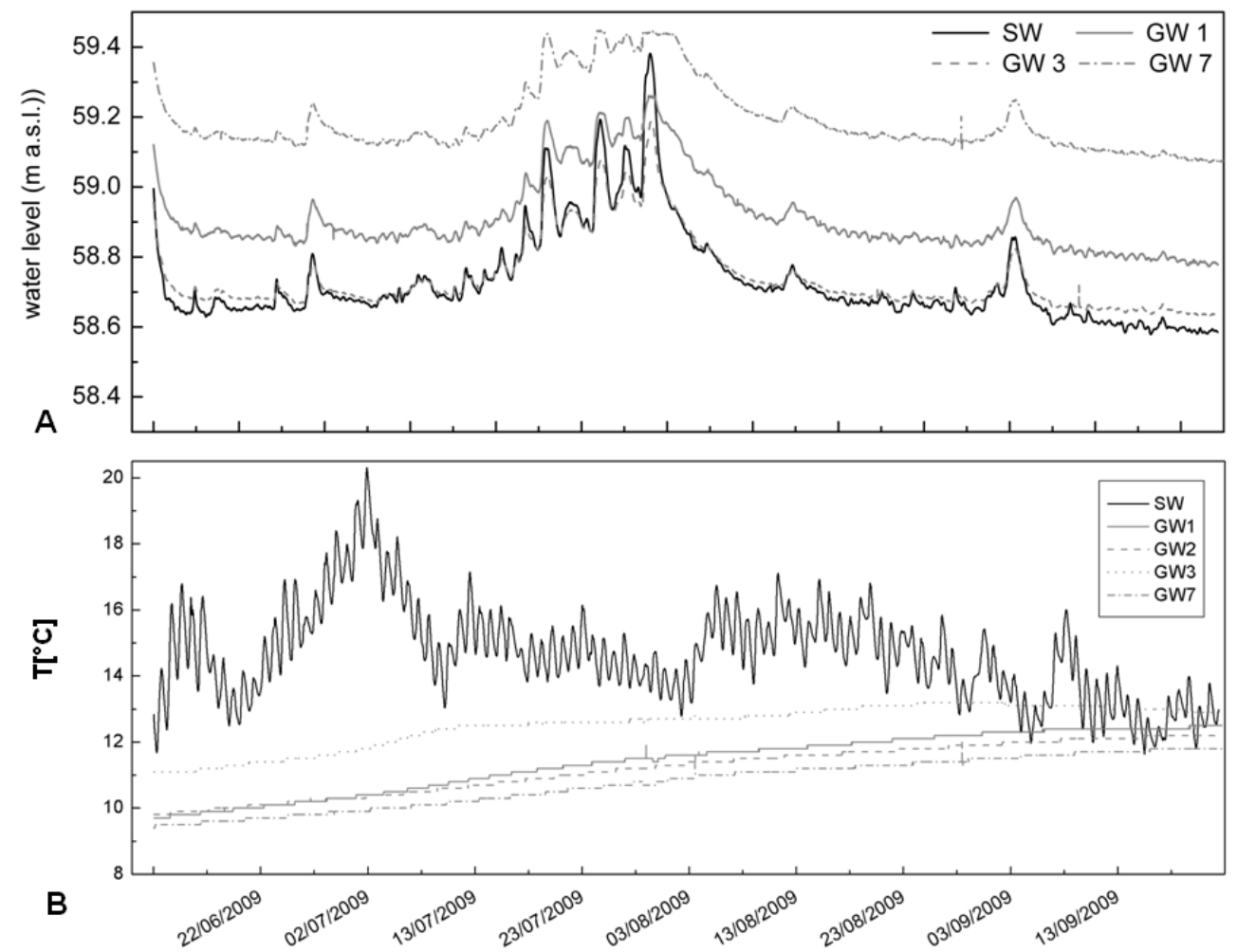

Fig. 5. (A): surface water levels (SW3, Fig. 1B) and groundwater heads measured at representative locations shown in Fig. 1 for the period of 1 June 2009-30 September 2009. (B): surface water and groundwater temperatures at the locations shown in Fig. 1 for the period of 1 June 2009-30 September 2009.

$\left(x_{i}\right)$ (see Sect. 2.3) to identify locations with signals that were significantly different to the average characteristics of the stream reach.

Figure 8a shows box-plot distributions of VHG anomalies $\left(A_{\mathrm{VHG}}\left(x_{i}\right)\right)$, i.e. the difference from the spatial average of each sampling date for each of the monitored piezometers (Eq. 2). This allowed the identification of (i) locations with generally higher or lower than average gradients over all sampling dates and (ii) locations showing more or less variability in time than the average. While VHGs at locations P4, P8, P12, P15, P18, P19, P22 and P23 were distinctly and persistently higher than average gradients, we also find locations where gradients were distinctly lower than average for all sampling dates (P6, P7, P11, P13, P14, P16, P17, P20 and $\mathrm{P} 27)$. VHGs in the up-stream and down-stream sections (P13 ; P25-26) were generally quite close to the spatial mean (anomaly $\approx 0$ ).

An analysis of the strength of temperature anomalies $A_{\mathrm{T}}$ $\left(x_{i}\right)$, based on FO-DTS observations (Fig. 8b), confirmed the heterogeneous temperature patterns in the streambed with a temperature variability of up to $2.3^{\circ} \mathrm{C}$. In addition to common temperature variations of $\pm 0.4^{\circ} \mathrm{C}$ around the spatial average, the box-plots also identified more substantial, temporally persistent cold spots with temperatures up to $1.8^{\circ} \mathrm{C}$ colder than the spatial average.
In order to analyse the temporal variability in the observed spatial patterns of temperature and VHGs, the temporal mean and standard deviation (STDEV) of anomaly strength of both VHG and temperature where compared (Fig. 9). This allowed for the testing of signal variability and robustness at locations where the temperatures or VHG differed strongly from the spatial average. The analysis was based on six FODTS temperature surveys and seven VHG observation dates (Table 1). STDEV for temperature anomalies varied between 0.02 and 0.51 . For VHGs the STDEV varied between 0.01 and 0.26 over all measurement locations.

While the relationship between STDEV and mean temperature anomalies exhibited a negative correlation with a spearman correlation coefficient of -0.78 (Fig. 9a), it was slightly positively correlated for the VHGs (Fig. 9b) with a spearman correlation coefficient of 0.47 . The STDEV of temperature anomalies were higher (ranging from 0.12-0.51) at locations with strong anomalies whereas at locations where temperatures were higher than the spatial average (anomaly $>0$ ), the STDEV values ranged from 0.02 to 0.20 (Fig. 9a). For locations with negative VHG anomalies, STDEVs were as low as $0.01-0.14$ but reached levels up to $0.025-0.26$ at locations with positive VHG anomalies (Fig. 9b).

Higher STDEV (Fig. 9e) observed at locations with strong negative anomalies in temperature (Fig. 9c) indicate that 


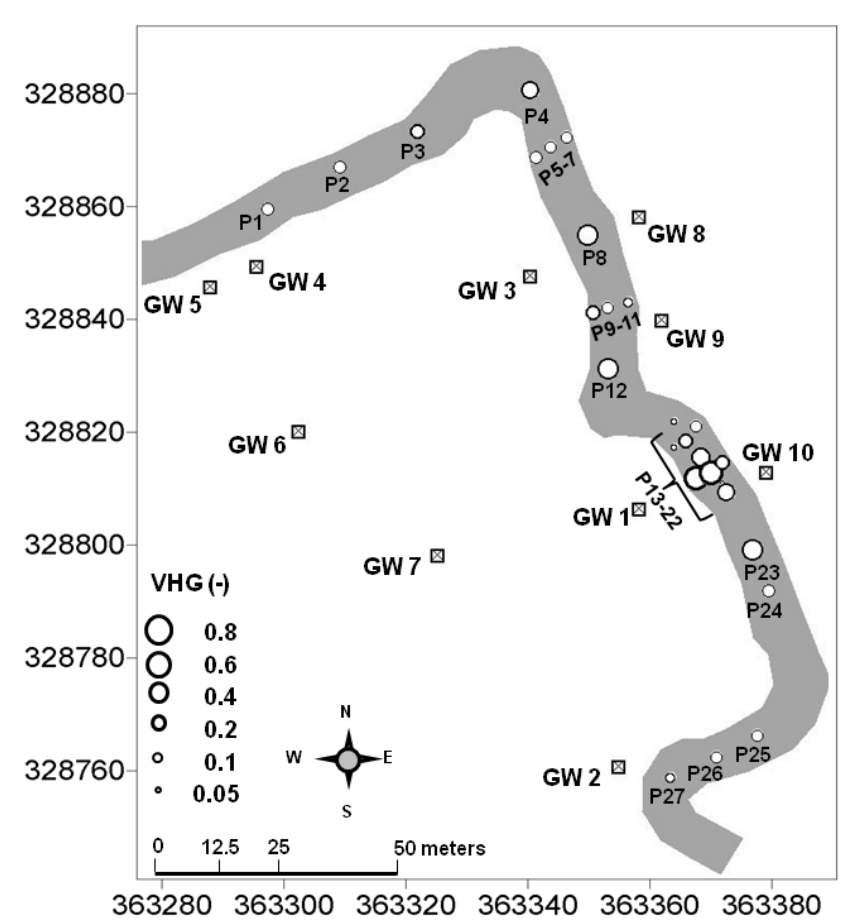

Fig. 6. Spatial patterns of average vertical hydraulic gradients at streambed piezometers $(\mathrm{P})$ for 7 sampling dates between 21 May30 September 2009 (see Table 1 for the exact dates).

these locations (cold spots) also exhibit more intense temporal signal variability than locations where temperatures differ less from the spatial average. VHG locations with negative anomalies (Fig. 9d) showed less temporal variability (Fig. 19f), whilst at locations with positive anomalies they were more variable in time, i.e. the VHG signal at high VHG locations varied more than at locations with low VHGs. Locations of lowest STDEV in VHG anomalies (Fig. 9f) coincided with areas of highest STDEV in FO-DTS anomalies (Fig. 9e).

\subsection{Streambed structural information}

Even though it was not possible to retrieve sediment cores for validation to the depth of installation for all piezometer locations, the multi-level mini-piezometers design (Fig. 3a) made an approximate estimation of flow confining peat and clay layers possible. Their small diameter $(1 \mathrm{~mm})$ prevented direct VHG observations at the sampling tubes bundled around the $150 \mathrm{~cm}$ deep central head observation tube with outlets at 15$20 \mathrm{~cm}$ vertical intervals (Fig. 3). However, low conductivity streambed zones could be identified at 8 sampling locations where no pore-water could be extracted (Table 2). Tests at selected locations such as CI and CII (Fig. 1) confirmed that inhibited pore-water extraction at piezometer sampling tubes coincided with streambed peat or clay layers.
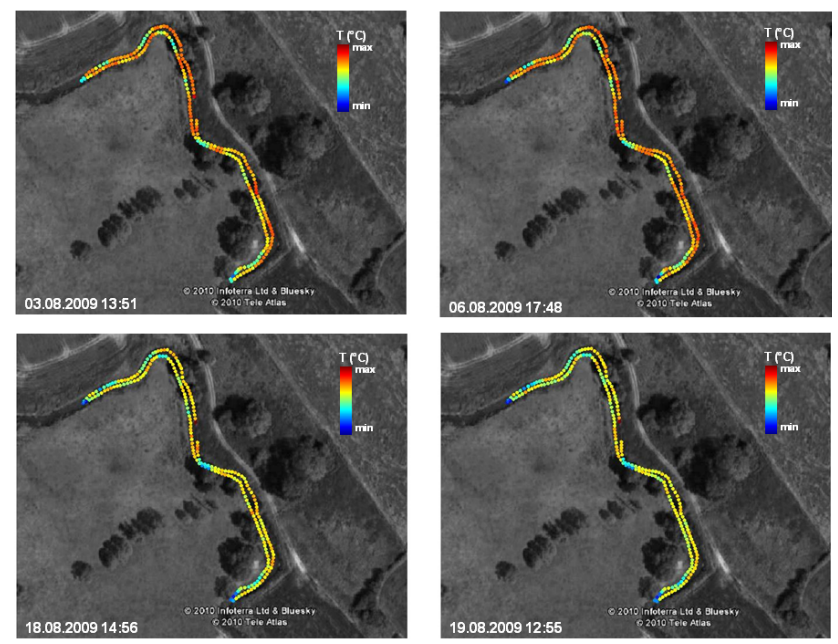

Fig. 7. Spatial patterns streambed temperature anomalies measured with FO-DTS on 4 representative sampling dates in August 2009. The colour scheme covers a range of $3^{\circ} \mathrm{C}$ for all 4 maps (absolute temperatures varied slightly from one sampling date to the other).

\section{Discussion}

\subsection{Analysis of aquifer-river connectivity by hydraulic head gradients}

Observed groundwater levels generally exceeded surface water levels (Fig. 5a), indicating groundwater flow towards the river. Inverse head gradients (surface water heads greater than groundwater heads), indicating surface water infiltration into the riparian groundwater, were limited to episodic storm events (Fig. 5a). The observed spatial variability in groundwater heads may result from spatially variable groundwater fluxes or heterogeneity in the hydraulic conductivities of riparian sediments, which varied by 5 orders of magnitude from highly conductive sands to low conductive clay (see Sect. 2.1). Groundwater and surface water responses to storm events (e.g. end of July 2009 - Fig. 4b) differed in intensity and timing. In comparison to the surface water, peaks in groundwater hydraulic heads were slightly delayed. Furthermore, peaks in groundwater heads exhibited a slower recession than in the surface water heads (Fig. 5a), which can be interpreted as the effect of retention by riparian storage.

Possible storm-flow related surface water infiltration, which was indicated by the continuous observations of groundwater and surface water hydraulic heads, was not evident during the VHG monitoring immediately after the event, suggesting that the duration of flow inversion was restricted to short episodes. However, this also means that the persistently positive VHG observed during the monitoring period limited the analysis of exchange fluxes in the research area to groundwater up-welling conditions.

The complex spatial patterns of observed VHGs (Fig. 6) could be interpreted as high spatial heterogeneity in 


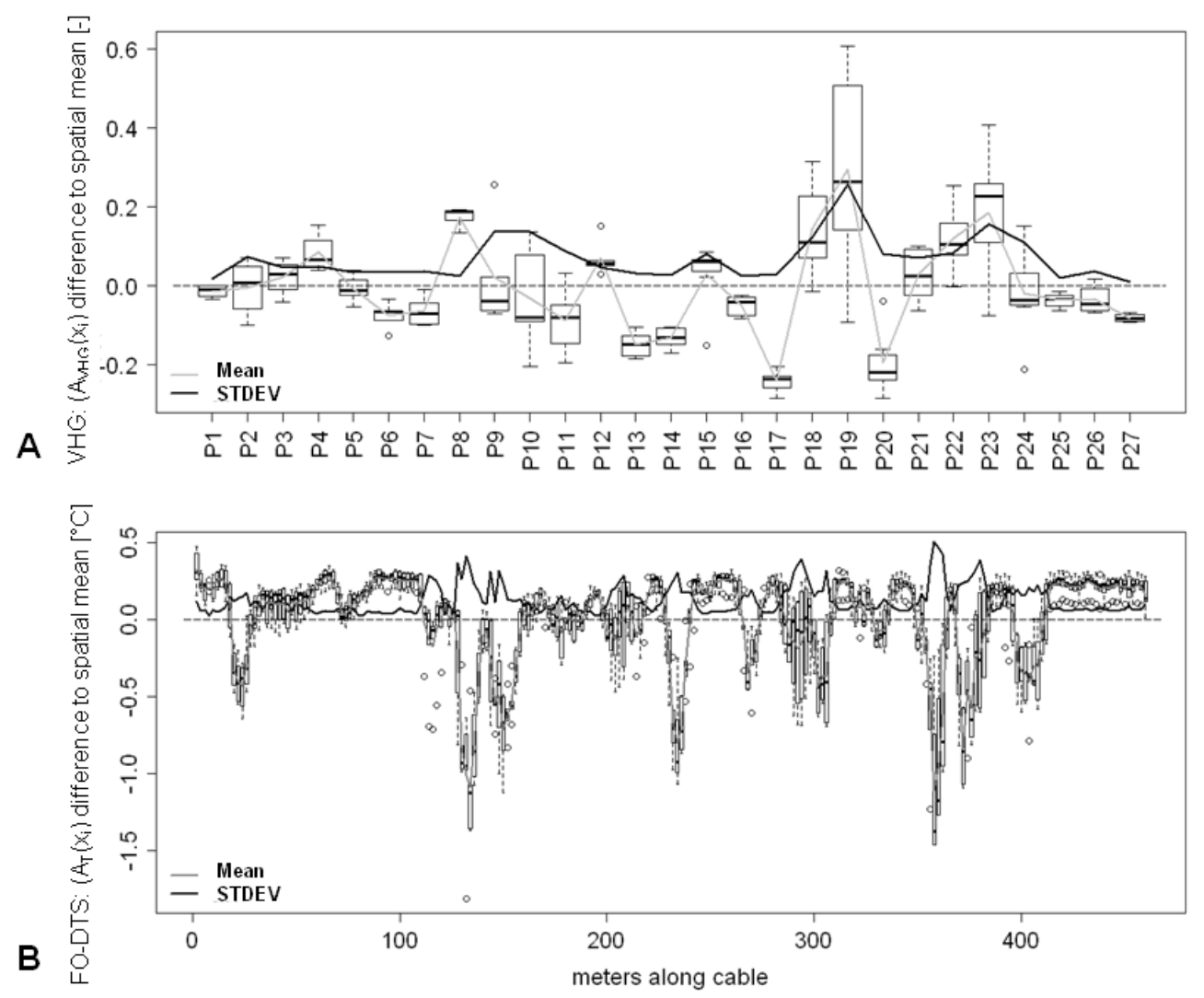

Fig. 8. (A) Box-plots of the temporal and spatial variability of vertical hydraulic gradients along the river reach (north to south) for 4-7 dates (depending on location). Values are standardized by subtracting the spatial mean at each sampling date. (B) Box-plots of the temporal and spatial variability of FO-DTS monitored temperatures along the fibre optic cable for all sampling dates. Values are standardized by subtracting the spatial mean at each sampling date.

groundwater up-welling. It is not feasible to directly infer fluxes from VHG observations as in streambeds with spatially highly variable hydraulic conductivities, VHGs have been found to be poor indicators of groundwater-surface water exchange (Käser et al., 2009). It is, therefore, not possible to discriminate whether VHG patterns result from spatial variability in groundwater flow or hydraulic conductivities without further detailed knowledge on the physical aquifer and streambed properties.

It is unlikely that the observed high VHG values indicate intensive groundwater up-welling induced by spatial heterogeneity in the regional groundwater flow as, for instance, caused by faults or fissures in the bedrock because the geological properties of the non-fractured Permo-Triassic sandstone aquifer at the research area are spatially very homogeneous. However, the streambed cores revealed substantial variability in the physical properties of the near-surface materials including highly variable hydraulic conductivities (Fig. 2). The spatially isolated high average VHG values of up to 0.6 (as seen in the central stream section) can be interpreted as indicators of the local inhibition of groundwater upwelling caused by the presence of flow confining streambed peat and clay lenses. At locations with lower (0.05-0.2) and spatially more homogeneous VHGs (i.e. the most up-stream and down-stream sections: P1-3 and P25-27; Fig. 6) this degree of flow inhibition is less likely.

High temporal variability ranges of VHG anomalies $A_{\text {VHG }}$ $\left(x_{i}\right)$ in the central river section (Fig. 8a) could be interpreted as an increased susceptibility of VHG to meteorologicallyinduced changes in larger-scale groundwater-surface water head ratios in the presence of flow confining streambed structures. In highly conductive sediments, when surface water heads react faster to storm events than groundwater heads, the resulting alteration of head differences between groundwater and surface water can be quickly equilibrated by exchange flow over the aquifer-river interface. Underneath flow confining streambed structures, however, floodinduced alteration of VHG anomalies would be more persistent as exchange between the groundwater and surface waters (and resulting head equilibration) would be inhibited. Any increased temporal variability in VHG anomalies could, therefore, be interpreted as further indication of flow confining conditions, whereas temporally stable VHG anomalies (as in the most up-stream and most down-stream sections, 

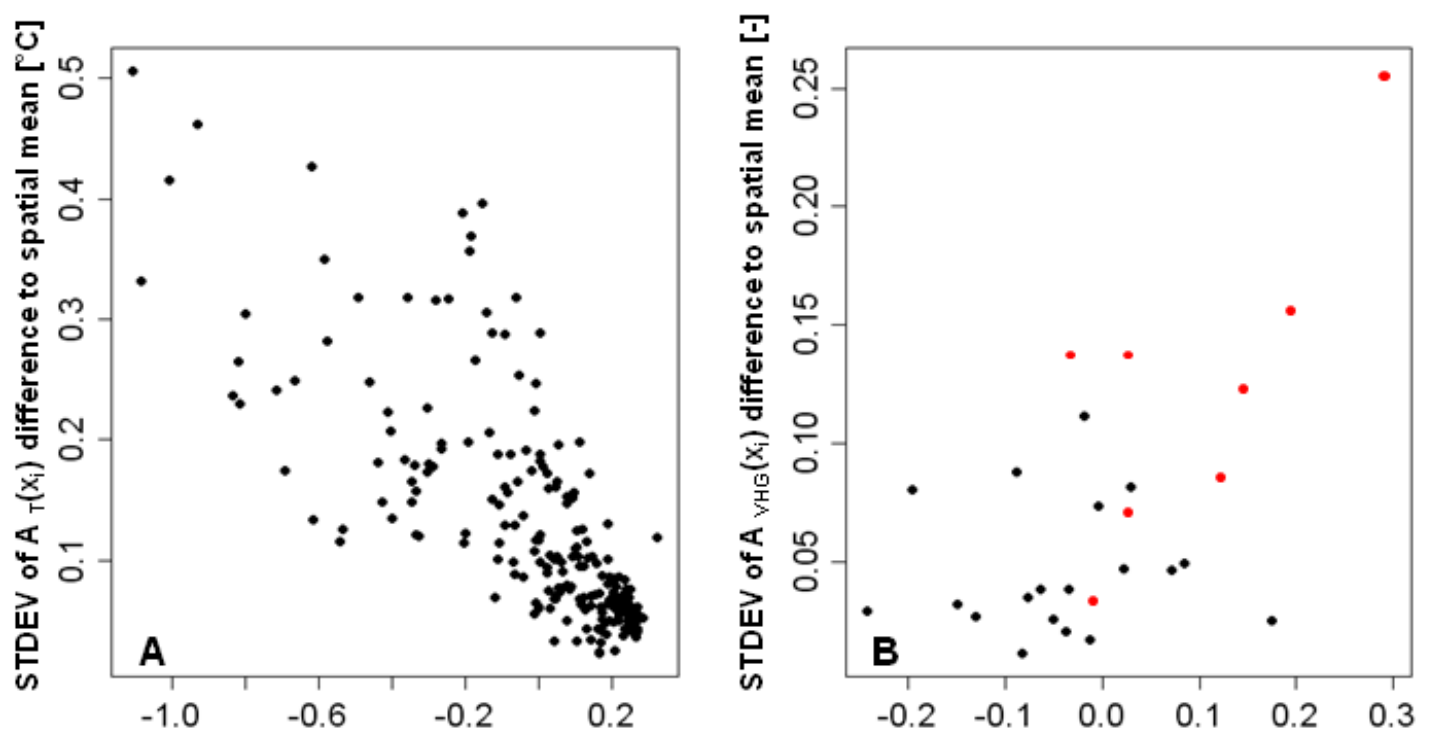

FO-DTS: mean $A_{T}\left(x_{i}\right)$ difference to spatial mean [ ${ }^{\circ} \mathrm{C}$ ] VHG: mean $A_{V H G}\left(x_{i}\right)$ difference to spatial mean [-]
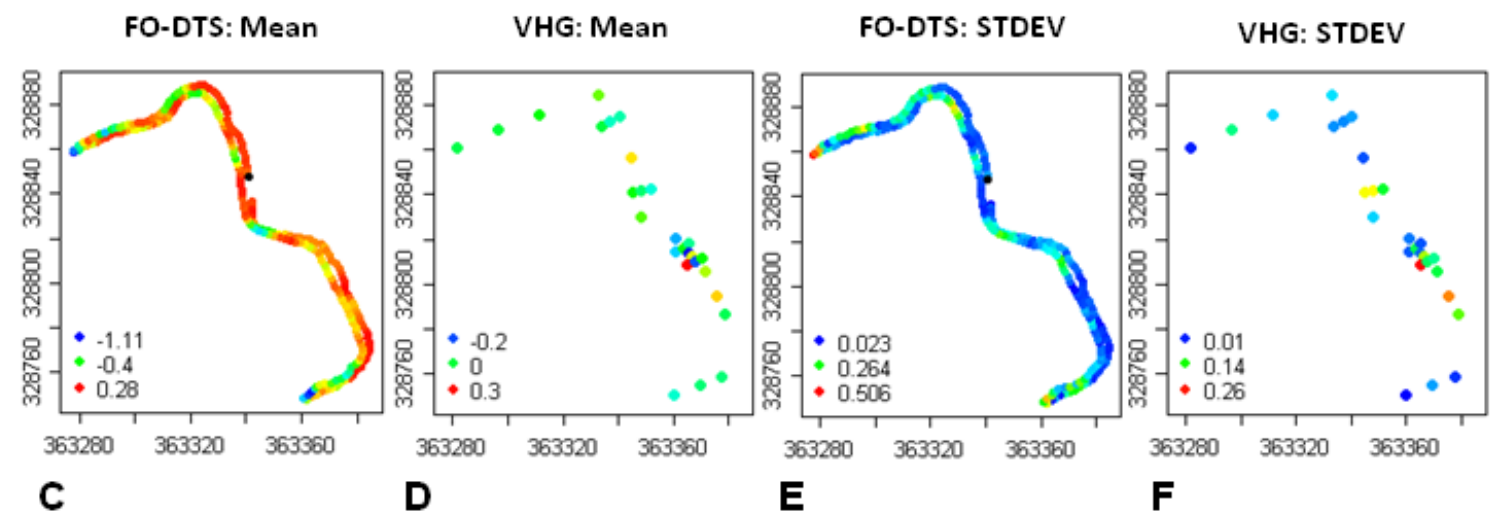

Fig. 9. Comparison of the temporal mean and standard deviation of signal strength for FO-DTS $A_{\mathrm{T}}\left(x_{i}\right)$ (A) and VHG $A_{\mathrm{VHG}}\left(x_{i}\right)$ (B). Red symbols indicate piezometers at locations with low conductivity flow confining streambed sediments; maps of the temporal mean of $A_{\mathrm{T}}\left(x_{i}\right)$ and $A_{\mathrm{VHG}}\left(x_{i}\right)$ for the FO-DTS and the VHG observations $(\mathbf{C}, \mathbf{D})$ and maps of the corresponding standard deviations of $A_{\mathrm{T}}\left(x_{i}\right)$ and $A_{\mathrm{VHG}}$ $\left(x_{i}\right)$ over all sampling dates $(\mathbf{E}, \mathbf{F})$.

Fig. 8a) could indicate highly conductive streambed sediments where groundwater-surface water head differences are faster equilibrated by exchange fluxes.

Nevertheless, without further detailed knowledge of the hydraulic conductivity patterns of the streambed sediments the above interpretations remain hypothetical, representing a particular limitation for VHG interpretations in structurally complex streambed environments. Table 2 confirms that VHG above the spatial average in many cases coincide with the observation of flow confining layers, indicating that high head gradients result from local inhibition of the groundwater up-welling. However, at other locations (e.g. P4, P8, P12, P20) this is not the case. High VHG at these piezometers adjacent to confined areas might indicate preferential pressure releases along intersecting flow paths resulting in locally intensified groundwater up-welling. A confirmation of these assumptions requires further information on actual groundwater up-welling patterns.

\subsection{Identification of groundwater-surface water exchange flow patterns by streambed temperature anomalies}

The time-series of temperature data revealed substantial differences between groundwater and river temperature dynamics. The temperature difference between groundwater and surface water in the period until the end of August 2009 (up to $9{ }^{\circ} \mathrm{C}$ ) provided a distinctive signal for tracing the exchange between the water sources at the aquifer-river interface (Fig. 5b).

The FO-DTS temperature monitoring within the sediment identified distinct cold spots along the streambed, 
Table 2. Average differences to spatial mean in VHG and FO-DTS monitored streambed temperatures (in direct vicinity to piezometer VHG observations) over the entire VHG and FO-DTS survey period in comparison to streambed structural information of up-welling inhibition. Case distinction of VHG vs. FO-DTS deviations from mean: CASE 1 = white, CASE $2=$ light grey, $C A S E 3=$ grey, $C A S E 4=$ dark grey.

\begin{tabular}{rrrr}
\hline $\begin{array}{r}\text { Piezo- } \\
\text { meter ID }\end{array}$ & $\begin{array}{r}\text { VHG difference } \\
\text { to spatial mean }\left(A_{\text {VHG }}\left(x_{i}\right)\right)\end{array}$ & $\begin{array}{r}\text { FO-DTS difference } \\
\text { to spatial mean }\left(A_{\mathrm{T}}\left(x_{i}\right)\right)\end{array}$ & $\begin{array}{r}\text { Flow confinement } \\
(\mathrm{y} / \mathrm{n})\end{array}$ \\
\hline P1 & -0.013 & -0.59 & No \\
P2 & -0.004 & -0.25 & No \\
P3 & 0.023 & -0.27 & No \\
P4 & 0.085 & -0.16 & Yes $(75 \mathrm{~cm})$ \\
P5 & -0.007 & +0.21 & No \\
P6 & -0.076 & +0.20 & No \\
P7 & -0.063 & +0.21 & -0.35 \\
P8 & 0.175 & 0.26 & Yes $(100 \mathrm{~cm})$ \\
P9 & 0.022 & 0.24 & Yes $(125 \mathrm{~cm})$ \\
P10 & -0.031 & 0.21 & No \\
P11 & -0.087 & -0.69 & No \\
P12 & 0.071 & 0.10 & No \\
P13 & -0.149 & -0.11 & No \\
P14 & -0.130 & 0.10 & No \\
P15 & 0.029 & 0.10 & No \\
P16 & -0.050 & 0.05 & Yes $(50-75 \mathrm{~cm})$ \\
P17 & -0.242 & 0.12 & No \\
P18 & 0.145 & 0 & Yes $(75 \mathrm{~cm})$ \\
P19 & 0.297 & 0.10 & No \\
P20 & -0.196 & 0.12 & Yes $(100-120 \mathrm{~cm})$ \\
P21 & 0.029 & 0.05 & Yes $(75-125)$ \\
P22 & 0.120 & 0.26 & Yes $(75 \mathrm{~cm})$ \\
P23 & 0.186 & 0.08 & No \\
P24 & -0.018 & -0.72 & No \\
P25 & -0.037 & -0.28 & No \\
P26 & -0.034 & -0.82 & No \\
P27 & -0.082 & & \\
& & & \\
& & & \\
& & &
\end{tabular}

indicating discrete up-welling patterns of colder groundwater (Fig. 7). Previous FO-DTS applications identified step functional changes of surface water column bottom temperatures as result of the warming or cooling effect of up-welling groundwater (Selker et al., 2006a; Westhoff et al., 2007).In contrast, roaming surveys of water column temperatures revealed that temperatures at the sediment/water column interface did not vary by more than $0.05^{\circ} \mathrm{C}$ along the investigated stream reach. The discrete nature of the distinct cold spots that have been identified in this study, indicate that streambed temperatures have been reduced only locally by up-welling groundwater (Fig. 7).

Although the signal strength $A_{\mathrm{T}}\left(x_{i}\right)$ determined by the range of local streambed temperature deviations from the spatial average, varied slightly throughout different observation dates, spatial temperature patterns remained constant and, therefore, seem to provide a robust indicator of groundwater up-welling locations (Fig. 8b). Persistently colder streambed temperatures were identified as groundwater upwelling hotspots at the most up-stream and down-stream sections (P1-3; P25-27) as well as at locations around piezome- ter $\mathrm{P} 4, \mathrm{P} 8$ and $\mathrm{P} 12$, whereas $2-2.3{ }^{\circ} \mathrm{C}$ higher temperatures for the rest of the river reach indicated no groundwater upwelling. Furthermore, since the temperature anomaly patterns proved to be temporally persistent, it can be assumed that locations of groundwater inflow were also stationary during the observation period. The high temporal variability at locations with strong temperature anomalies is likely to result from variable groundwater up-welling causing a range of mixing temperatures.

With up to $1.8^{\circ} \mathrm{C}$ of spatial variation between identified up-welling and non-up-welling locations, the signal strength is significantly higher (> five times) than topography-driven temperature variability at the streambed surface. Temperature differences caused by spatial variability in heat conduction and streambed topography has been identified not to exceed $0.3{ }^{\circ} \mathrm{C}$ in a previous study (Krause et al., 2011b) and is, therefore, likely to cause only minor uncertainty in the FO-DTS data interpretation. It is important to note that the effects of solar radiation and shading on the streambed temperatures can be excluded as the stream flow velocities of persistently $>0.4 \mathrm{~m} \mathrm{~s}^{-1}$, average water depths of $0.5-1.5 \mathrm{~m}$ 
and discharges of $Q>0.5 \mathrm{~m}^{3} \mathrm{~s}^{-1}$ during the observation period would prevent the shading-related cooling as well as direct radiation induced preferential heating of the bottom of the water column.

\subsection{Synthesis: conjunctive interpretation of VHG and temperature information for identifying exchange flow patterns in dependence of aquifer-river connectivity}

While FO-DTS observed streambed temperature distributions represent a powerful indicator of groundwater upwelling, they do not provide an insight into why groundwater is up-welling at distinct locations. Similarly, it is not possible to adequately infer groundwater-surface water exchange fluxes from VHG observations alone without detailed knowledge of streambed physical properties. However, by combining FO-DTS-derived streambed temperatures with VHGs, further insights into the nature of streambed controls on groundwater-surface water exchange in the investigated lowland stream section can be obtained.

\subsubsection{A framework for process inference}

High hydraulic fluxes can result either from high pressure gradients or high permeabilities. For summer conditions in groundwater gaining streams we suggest the following framework of process inferences:

CASE 1: under conditions where strong cold temperature anomalies suggest high groundwater inflow, it can be assumed that the coincidence of high VHG with strong streambed temperature anomalies indicates intensive groundwater up-welling. Such conditions might particularly be encountered at locations of preferential pressure release through highly conductive sediments adjacent to flow confining streambed structures.

CASE 2: alternatively, the occurrence of low VHG and small streambed temperature anomalies indicates locations of no or reduced groundwater up-welling which could result from these areas being bypassed by the regionally upwelling groundwater (e.g. due to preferential lateral flow) or flow confining streambed structures beneath the zone of investigations.

CASE 3: however, if high VHG anomalies do not coincide with strong temperature anomalies this indicates that up-welling pressure gradients exist but the flow is locally inhibited by low conductivity streambed sediments.

CASE 4: in contrast, low VHG anomalies at locations with strong streambed temperature anomalies can indicate groundwater up-welling through highly conductive streambed sediments.

\subsubsection{Application and validation of the framework}

In the research area, CASE 4 conditions can be found at the P1-2 and P25-27 northern and southern ends of the reach, where significant temperature differences from the spatial average (Fig. 9c) coincide with generally low to moderate VHG anomalies (Fig. 9d), indicating strong groundwater up-welling through moderate to highly conductive streambed sediments. At these locations, as well as locations P6-7, P10-11, P13-17 and P24, which represent characteristic CASE 2 conditions with low deviation from spatial average temperatures (Fig. 9c) and VHG's (Fig. 9d), no flow confining structures have been detected along the streambed piezometers (Table 2). In contrast, the moderateto-high VHG anomalies around piezometer P5, P9, P18-19 and section P21-23 (Figs. 6 and 9d) coincide with only minor streambed temperature anomalies (Fig. 9c), indicating up-welling inhibition by confining streambed sediments (corresponding with CASE 3 conditions). This interpretation is confirmed by the observation of flow confining streambed layers in the respective piezometers (Table 2, Fig. 6). In particular around piezometers P3, P4, P8 and P12, which represent locations without flow confining sediment structures but within close vicinity to identified low conductivity sediments (Table 2), high VHG anomalies (Fig. 9d) coincide with high temperature anomalies (Fig. 9c). This indicates CASE 1 conditions with intensive up-welling along preferential pressure release flow paths.

As already suggested by Fig. 9a, the temporal variability (STDEV) in the temperature signal strength $A_{\mathrm{T}}\left(x_{i}\right)$ is generally larger at locations of high temperature anomalies where local temperatures were below the spatial average (Fig. 9e). It also appears that piezometers close to locations of FO-DTS indicating groundwater up-welling (high $A_{\mathrm{T}}\left(x_{i}\right)$ ) are characterised by lower temporal variability (STDEV) of $A_{\mathrm{VHG}}$ $\left(x_{i}\right)$ ) (Fig. 9f). This supports the hypothesis that high temporal variability of VHG anomalies $A_{\mathrm{VHG}}\left(x_{i}\right)$ is more closely connected to up-welling inhibition by low permeability barriers (see Sect. 4.1) than with groundwater influx into the river. This assumption is confirmed by the observation that at locations with up-welling inhibition highest VHG anomalies $A_{\mathrm{VHG}}\left(x_{i}\right)$ coincide with high STDEV in signal strength (Fig. 9b).

\subsubsection{Implications and limitations in transferability of the framework to other flow systems}

The approach presented in this paper has the potential for advancing the mechanistic understanding of aquifer-river exchange at a broad range of spatial scales, extending current knowledge based on previous studies at stream reaches of several meters (e.g. Kasahara and Wondzell, 2003; Hannah et al., 2009; Käser et al., 2009; Krause et al., 2009b, 2011b; Rosenberry and Pitlick, 2009) to potentially several kilometers. In contrast to other experimental methods for the analysis of exchange flow patterns, as for instance seepage meters (Rosenberry, 2008) or heat tracing (Constantz et al., 2008; Hatch et al., 2010), including the application of FO-DTS (Selker et al., 2006a, b; Westhoff et al., 2007), the presented 
approach of combined FO-DTS and VHG monitoring allows to discriminate between drivers and controls of exchange fluxes. It supports the identification of spatial patterns in exchange fluxes and residence time distributions, and has the potential to significantly improve the understanding of residence time controlled biogeochemical activity and detection of reactive hotspots in streambed environments (Pinay et al., 2009; Zarnetske et al., 2011a, b).

However, the framework of process interference is tested in this study for summer baseflow conditions in a groundwater gaining lowland stream. Although adaptations of the approach are expected to be transferable to different systems, its applicability for other conditions requires further validation. Patterns and dynamics of temperature and VHG anomalies will be different for instance for winter conditions (with inverse temperature gradients) as well as for loosing stream reaches with negative VHG gradients. Periods of flow inversion with down-welling of surface water were limited in their duration and not evident during VHG surveys. This restricts our analysis to groundwater up-welling conditions and thus, the discussion of loosing conditions is so far purely hypothetical. For example, in case of a river with similar groundwater-surface water thermal differences during summer, low streambed permeability with discrete locations where the stream was losing water would be expected to cause warm temperature anomalies. The temporal variation of the strength of warm anomalies would be likely to be higher than the variability of the cold anomalies observed in this study as the intensity of the temperature signal would be controlled by (i) the fluctuation in hydraulic gradients and (ii) the temporal variability in surface water temperature. Temporal dynamics of both can be expected to be higher than in groundwater, likely to result in increased temporal variability of warm anomaly signal strength (as compared to the cold anomalies in the present study).

Our results differ from a number of previous FO-DTS applications with fibre-optic cables placed on the sediment surface (e.g. Selker et al., 2006a, b; Westhoff et al., 2007; Slater et al., 2010), which found the up-welling of groundwater to effect the bottom temperatures of the surface water column. In particular in headwater streams, these temperature effects propagated down-stream (Selker et al., 2006a, b; Westhoff et al., 2007). In contrast to these studies, proportionally smaller groundwater contributions to the overall discharge in the investigated stream section did only cause local, spatially very discrete temperature anomalies within the streambed and did not influence temperature further down-stream.

The presented methodology based on streambed temperature patterns by FO-DTS, strongly relies on the ability to correctly deploy the fibre-optic cable within the streambed sediments. At locations, where field conditions prevent the installation of fibre-optic cables within the streambed (as for instance in Selker et al., 2006a; Westhoff et al., 2007; Slater et al., 2010), the applicability of the presented approach might be limited. In particular in environments with small rela- tive groundwater contributions to the stream discharge, the groundwater temperature signal is likely to attenuate very quickly within the surface water column. Potential future applications of the presented approach in different environmental settings will need to ensure that more pronounced diurnal surface water temperature amplitudes or preferential heating or shading of the streambed do not critically interfere with the application of temperature as a tracer of aquifer-river exchange flow patterns.

\section{Conclusions}

The results of this study demonstrate the potential of FODTS observations along a fibre-optic cable buried in the streambed for tracing complex patterns of exchange fluxes across the aquifer-river interface of larger lowland rivers. FO-DTS monitored temperature patterns in the research area revealed distinct up-welling hotspots in the streambed. The results of this study provide strong evidence for the advantage of FO-DTS monitoring in systems where traditional roaming temperature surveys of larger areas or a limited number of temperature profiles in the streambed sediments have a high probability of not capturing the very distinct and localized hotspots of groundwater inflow.

Although streambed VHG patterns identified in this study were not suitable for directly determining groundwatersurface water exchange fluxes, when combined with FODTS observations of streambed temperature anomalies, they proved a useful indicator for the discrimination of driving forces and inhibitors of exchange over the aquifer-river interface. The comparison of patterns in VHG and FODTS monitored temperature anomalies provides a powerful framework for the identification of aquifer-river exchange flow in dependence of streambed hydraulic conductivity patterns. Our results illustrate the value of combining observations of VHG and FO-DTS sampled temperature patterns for improving the understanding of drivers and controls of groundwater-surface water exchange in lowland rivers with complex small-scale patterns in streambed transmissivity. By using comparative FO-DTS and VHG observations as a hypotheses testing tool, this study furthermore provides a successfully validated strategy for the optimisation of experimental design in lowland river streambeds with limited information on streambed structure and physical properties.

The presented approach has, in this study, been validated for summer baseflow conditions in lowland rivers where discharge of cold groundwater is causing anomalies in streambed temperature patterns and vertical hydraulic gradients. Future research should focus on testing the applicability of the presented methodology and adapting it for contrasting streambed environments, including winter conditions (with inverse temperature gradients) as well as loosing streams. 
Acknowledgements. The authors wish to acknowledge support of the presented work by the Royal Geographical Society, EPSRC and NERC (NE/I016120). We would also like to thank Fred Day-Lewis (USGS) for the kind provision of the FO-DTS mapping scripts, Kevin Voyce (Environment Agency of England and Wales) for hydro-meteorological data and Emma Naden (University of Keele), Christina Tecklenburg and Mathias Munz (University of Potsdam) for fieldwork support.

Edited by: M. Weiler

\section{References}

Anderson, M. P.: Heat as a Ground Water Tracer, Ground Water, 43, 951-968, 2005.

Anibas, C., Fleckenstein, J. H., Volze, N., Buis, K., Verhoeven, R., Meire, P., and Batelaan, O.: Transient or Steady-state? Using vertical temperature profiles to quantify groundwater-surface water exchange, Hydrol. Process., 23, 2165-2177, 2009.

Bencala, K. E.: A perspective on stream-catchment connections, J. N. Am. Benthol. Soc., 1, 44-47, 1993.

Boano, F., Camporeale, C., Revelli, R., and Ridolfi, L.: Sinuositydriven hyporheic exchange in meandering rivers, Geophys. Res. Lett., 33, 1-4, 2006.

Boano, F., Demaria, A., Revelli, R., and Ridolfi, L.: Biogeochemical zonation due to intrameander hyporheic flow, Water Resour. Res., 46, W02511, doi:10.1029/2008WR007583, 2010.

Boulton, A. J.: Hyporheic rehabilitation in rivers: restoring vertical connectivity, Freshwater Biol., 52, 632-650, 2007.

Boulton, A. J., Findlay, S., Marmonier, P., Stanley, E. H., and Valett, H. M.: The functional significance of the hyporheic zone in streams and rivers, Annu. Rev. Ecol. Syst., 29, 59-81, 1998.

Brunke, M. and Gonser, T.: The ecological significance of exchange processes between rivers and groundwater, Freshwater Biol., 37, 1-33, 1997.

Calver, A.: Riverbed permeabilities: Information from pooled data, Ground Water, 39, 546-553, 2001.

Cardenas, M. B.: Stream-aquifer interactions and hyporheic exchange in gaining and losing sinuous streams, Water Resour. Res., 45, W06429, doi:10.1029/2008WR007651, 2009.

Cardenas, M. B. and Wilson, J. L.: The influence of ambient groundwater discharge on exchange zones induced by currentbedform interactions, J. Hydrol., 331, 103-109, 2006.

Cardenas, M. B. and Wilson, J. L.: Thermal regime of dune-covered sediments under gaining and losing water bodies, J. Geophys. Res., 112, G04013, doi:10.1029/2007JG000485, 2007.

Cardenas, M. B., Wilson, J. L., and Zlotnik, V. A.: Impact of heterogeneity bedform configuration, and channel curvature on hyporheic exchange, Water Resour. Res., 40, W08307, doi:10.1029/2004WR003008, 2004.

Cardenas, M. B., Wilson, J. L., and Haggerty, R.: Residence time of bedform-driven hyporheic exchange, Adv. Water Res., 31, 13821386, 2008.

Chafiq, M., Gibert, J., and Claret, C.: Interactions among sediments, organic matter and microbial activity in the hyporheic zone of an intermittent stream, Can. J. Fish. Aquat. Sci., 56, 487-495, 1999.

Conant, B.: Delineating and quantifying ground water discharge zones using streambed temperatures, Ground Water, 42, 243257, 2004.
Constantz, J.: Heat as a tracer to determine streambed water exchanges, Water Resour. Res., 44, W00D10, doi:10.1029/2008WR006996, 2008.

Constantz, J., Tyler, S. W., and Kwicklis, E.: Temperature-profile methods for estimating percolation rates in arid environments, Vadose Zone J., 2, 12-24, 2003.

Dole-Olivier, M. J., Marmonier, P., and Beffy, J. L.: Response of invertebrates to lotic disturbance: Is the hyporheic zone a patchy refugium?, Freshwater Biol., 37, 257-276, 1997.

Duff, J. H. and Triska, F. J.: Denitrification in the sediments from the hyporheic zone adjacent to a small forested stream, Can. J. Fish. Aquat. Sci., 47, 1140-1147, 1990.

Duff, J. H. and Triska, F. J.: Nitrogen biochemistry and surfacesubsurface exchange in streams, in: Streams and Groundwater, edited by: Jones, J. B. and Mulholland, P. J., Academic Press, London, 197-220, 2000.

Engdahl, N. B., Vogler, E. T., and Weissmann, G. S.: Evaluation of aquifer heterogeneity effects on river flow loss using a transition probability framework, Water Resour. Res., 46, W01506, doi:10.1029/2009WR007903, 2010.

Findlay, S., Strayer, D., Goumbala, C., and Gould, K.: Metabolism of streamwater dissolved organic carbon in the shallow hyporheic zone, Limnol. Oceanogr., 38, 1493-1499, 1993.

Findlay, S. E. G., Sinsabough, R. L., Sobczak, W. V., and Hoostal, M.: Metabolic and structural response of hyporheic microorganisms to variations in supply of dissolved organic matter, Limnol. Oceanogr., 48, 1608-1617, 2003.

Fisher, S. G., Grimm, N. B., Marti, E., Holmes, R. M., and Jones, J. B.: Material spiraling in stream corridors: A telescoping ecosystem model, Ecosystems, 1, 19-34, 1998.

Fleckenstein, J. H., Niswonger, R. G., and Fogg, G. E.: Riveraquifer interactions, geologic heterogeneity, and low-flow management, Ground Water, 44, 837-852, 2006.

Frei, S., Fleckenstein, J. H., Kollet, S. J., and Maxwell, R. M.: Patterns and dynamics of river-aquifer exchange with variablysaturated flow using a fully-coupled model, J. Hydrol., 375, 383393, 2009.

Genereux, D. P., Leahy, S., Mitasova, H., Kennedy, C. D., and Corbett, D. R.: Spatial and temporal variability of streambed hydraulic conductivity in West Bear Creek, North Carolina, USA, J. Hydrol., 358, 332-353, 2008.

Hannah, D. M., Malcolm, I. A., Soulsby, C., and Youngson, A. F.: Heat exchanges and temperatures within a salmon spawning stream in the Cairngorms, Scotland: seasonal and sub-seasonal dynamics, River Res. Appl., 20, 635-652, 2004.

Hannah, D. M., Malcolm, I. A., and Bradley, C.: Seasonal hyporheic temperature dynamics over riffle bedforms, Hydrol. Process., 23, 2178-2194, 2009.

Hatch, C. E., Fisher, A. T., Ruehl, C. R., and Stemler, G.: Spatial and temporal variations in streambed hydraulic conductivity quantified with time-series thermal methods, J. Hydrol., 389, 276-288, doi:10.1016/j.jhydrol.2010.05.046, 2010.

Hill, A. R. and Cardaci, M.: Denitrification and organic carbon availability in riparian wetland soils and subsurface sediments, Soil Sci. Soc. Am. J., 68, 320-325, 2004.

Hinkle, S. R., Duff, J. H., Triska, F. J., Laenen, A., Gates, E. B., Bencala, K. E., Wentz, D. A., and Silva, S. R.: Linking hyporheic flow and nitrogen cycling near the Willamette River - a large river in Oregon, USA, J. Hydrol., 244, 157-180, 2001. 
Hoes, O. A. C., Luxemburg, W. M. J., Westhof, M. C., van de Giesen, N. C., and Selker, J.: Identifying seepage in ditches and canals in ploders in The Netherlands by distributed temperature sensing, Lowland Technology International, 11, 21-26, 2009.

Jones, J. B., Holmes, R. M., Fisher, S. G., Grimm, N. B., and Greene, D. M.: Methanogenesis In Arizona, Usa Dryland Streams, Biogeochemistry, 31, 155-173, 1995.

Kasahara, T. and Hill, A. R.: Modeling the effects of lowland stream restoration projects on stream-subsurface water exchange, Ecol. Eng., 32, 310-319, 2008.

Kasahara, T. and Wondzell, S. M.: Geomorphic controls on hyporheic exchange flow in Mountain Streams, Water Resour. Res., 39, 1-14, 2003

Käser, D., Binley, A., Heathwaite, L., and Krause, S.: Spatiotemporal variations of hyporheic flow in a riffle-step-pool sequence, Hydrol. Process., 23, 2138-2149, 2009.

Keery, J., Binley, A., Crook, N., and Smith, J. W. N.: Temporal and spatial variability of groundwater-surface water fluxes: development and application of an analytical method using temperature time series, J. Hydrol., 336, 1-16, 2007.

Krause, S., Heathwaite, A. L., Miller, F., Hulme, P., and Crowe, A.: Groundwater-dependent wetlands in the UK and Ireland: controls, eco-hydrological functions and assessing the likelihood of damage from human activities, J. Water Resour. Manage., 21, 2015-2025, 2008a.

Krause, S., Jacobs, J., Habeck, A., Bronstert, A., and Zehe, E.: Assessing the impact of changes in landuse and management practices on the diffusive pollution and retention of nitrate in a riparian floodplain, Sci. Total Environ., 389, 149-164, 2008b.

Krause, S., Hannah, D. M., and Fleckenstein, J. H.: Hyporheic hydrology: interactions at the groundwater-surface water interface, Hydrol. Process., 23, 2103-2107, 2009a.

Krause, S., Heathwaite, A. L., Binley, A., and Keenan, P.: Nitrate concentration changes along the groundwater - surface water interface of a small Cumbrian river, Hydrol. Process., 23, 21952211, 2009b.

Krause, S., Hannah, D. M., Fleckenstein, J. H., Heppell, C. M., Pickup, R., Pinay, G., Robertson, A. L., and Wood, P. J.: Interdisciplinary perspectives on processes in the hyporheic zone, Ecohydrol. J., 4, 1-19, 2011 a.

Krause, S., Hannah, D. M., and Blume, T.: Heat transport patterns at pool-riffle sequences of an UK lowland stream, Ecohydrol. J., 4, 549-563, doi:10.1002/eco.199, 2011b.

Krause, S., Hannah, D. M., Wood, P. J., and Sadler, J.: Hydrology and Ecology interfaces: processes and interactions in wetland, riparian and groundwater-based ecosystems, Ecohydrology , 4, 476-480, 2011c.

Leek, R., Wu, J. Q., Wang, L., Hanrahan, T. P., Barber, M. E., and Qiu, H.: Heterogeneous characteristics of streambed saturated hydraulic conductivity of the Touchet River, south eastern Washington, USA, Hydrol. Process., 23, 1236-1246, doi:10.1002/hyp.7258, 2009.

Lowry, C. S., Walker, J. F., Hunt, R. J., and Anderson, M. P.: Identifying spatial variability of groundwater discharge in a wetland stream using a distributed temperature sensor, Water Resour. Res., 43, W10408, doi:10.1029/2007WR006145, 2007.

Malard, F., Ferreira, D., Doledec, S., and Ward, J. V.: Influence of groundwater upwelling on the distribution of the hyporheos in a headwater river flood plain, Arch. Hydrobiol., 157, 89-116,
2003.

Malcolm, I. A., Soulsby, C., and Youngson, A. F.: Thermal regime in the hyporheic zone of two contrasting salmonid spawning streams, Fisheries Manag. Ecol., 9, 1-10, 2002.

Malcolm, I. A., Soulsby, C., Youngson, A. F., Hannah, D. M., McLaren, I. S., and Thorne, A.: Hydrological influences on hyporheic water quality: implications for salmon survival, Hydrol. Process., 18, 1543-1560, 2004.

Mulholland, P. J., Tank, J. L., Sanzone, D. M., Wollheim, W. M., Peterson, B. J., Webster, J. R., and Meyer, J. L.: Nitrogen cycling in a forest stream determined by a $15 \mathrm{~N}$ tracer addition, Ecol. Monogr., 70, 471-493, 2000.

Mulholland, P. J., Helton, A. M., Poole, G. C., Hall, R. O., Hamilton, S. K., Peterson, B. J., Tank, J. L., Ashkenas, L. R., Cooper, L. W., Dahm, C. N., Dodds, W. K., Findlay, S. E. G., Gregory, S. V., Grimm, N. D., Johnson, S. L., McDowell, W. H., Meyer, J. L., Valett, H. M., Webster, J. R., Arango, C. P., Beaulieu, J. J., Bernot, M. J., Burgin, A. J., Crenshaw, C. L., Johson, L. T., Niederlehner, B. R., O'Brien, J. M., Potter, J. D., Sheibley, R. W., Sobota, D. J., and Thomas, S. M.: Stream denitification across biomes and its response to anthropogenic nitrate loading, Nature, 452, 202-205, 2008.

Pinay, G., O'Keefe, T. C., Edwards, R. T., and Naiman, R. J.: Nitrate removal in the hyporheic zone of a salmon river in Alaska, River Res. Appl., 25, 367-375, 2009.

Robertson, A. L. and Wood, P. J.: Ecology of the hyporheic zone: origins, current knowledge and future directions, Fund. Appl. Limnol., 176, 277-289, 2010.

Rosenberry, D. O.: A seepage meter designed for use in flowing water, J. Hydrol., 359, 118-130, 2008.

Rosenberry, D. O. and Pitlick, J.: Local-scale spatial and temporal variability of seepage in a shallow gravel-bed river, Hydrol. Process., 23, 3306-3318, 2009.

Schmidt, C., Conant, B., Bayer-Raich, M., and Schirmer, M.: Evaluation and field-scale application of an analytical method to quantify groundwater discharge using mapped streambed temperatures, J. Hydrol., 347, 292-307, 2007.

Selker, J. S.: Taking the temperature of ecological systems with fibre-optics, EOS. Trans. AGU, 89, 187, doi:10.1029/2008EO200007, 2008.

Selker, J. S., van de Giesen, N., Westhoff, M., Luxemburg, W., and Parlange, M. B.: Fiber optics opens window on stream dynamics, Geophys. Res. Lett., 33, L24401, doi:10.1029/2006GL027979, 2006a.

Selker, J. S., Thévenaz, L., Huwald, H., Mallet, A., Luxemburg, W., van de Giesen, N., Stejskal, M., Zeman, J., Westhoff, M., and Parlange, M. B.: Distributed fiber optic temperature sensing for hydrologic systems, Water Resour. Res., 42, W12202, doi:10.1029/2006WR005326, 2006b.

Slater, L. D., Ntarlagiannis, D., Day-Lewis, F. D., Mwakanyamale, K., Versteeg, R. J., Ward, A., Strickland, C., Johnson, C. D., and Lane Jr., J. W.: Use of electrical imaging and distributed temperature sensing methods to characterize surface water groundwater exchange regulating uranium transport at the Hanford 300 Area, Washington, Water Resour. Res., 46, W10533, doi:10.1029/2010WR009110, 2010.

Sophocleous, M.: Interactions between groundwater and surface water: the state of science, Hydrogeol. J., 10, 52-67, 2002. 
Storey, R. G., Howard, K. W. F., and Williams, D. D.: Factors controlling riffle-scale hyporheic exchange flows and their seasonal changes in a gaining stream: A three-dimensional groundwater flow model, Water Resour. Res., 39, 1034, doi:10.1029/2002WR001367, 2003.

Storey, R. G., Williams, D. D., and Fulthorpe, R. R.: Nitrogen Processing In The Hyporheic Zone Of A Pastoral Stream, Biogeochemistry, 69, 285-313, 2004.

Stubbington, R., Wood, P. J., and Boulton, A. J.: Low flow controls on benthic and hyporheic macroinvertebrate assemblages during a supra-seasonal drought, Hydrol. Process., 23, 2252-2264, 2009.

Tonina, D. and Buffington, J. M.: Hyporheic exchange in gravel bed rivers with pool-riffle morphology: laboratory experiments and three-dimensional modelling, Water Resour. Res., 43, W01421, doi:10.1029/2005WR004328, 2007.

Tyler, S. W., Selker, J. S., Hausner, M. B., Hatch, C. E., Torgersen, T., Thodal, C. E., and Schladow, S. G.: Environmental temperature sensing using Raman spectra DTS fiber-optic methods, Water Resour. Res., 45, W00D23, doi:10.1029/2008WR007052, 2009.

Webb, B. W., Hannah, D. M., Moore, R. D., Brown, L. E., and Nobilis, F.: Recent advances in stream and river temperature research, Hydrol. Process., 22, 902-918, 2008.
Westhoff, M. C., Savenije, H. H. G., Luxemburg, W. M. J., Stelling, G. S., van de Giesen, N. C., Selker, J. S., Pfister, L., and Uhlenbrook, S.: A distributed stream temperature model using high resolution temperature observations, Hydrol. Earth Syst. Sci., 11, 1469-1480, doi:10.5194/hess-11-1469-2007, 2007.

White, D. S.: Perspectives on defining and delineatinghyporheic zones, J. N. Am. Bentholog. Soc., 12, 61-69, 1993.

Woessner, W. W.: Stream and fluvial plain ground water interactions: rescaling hydrogeologic thought, Ground Water, 38, 423 429, 2000.

Wondzell, S. M.: Effect of morphology and discharge on hyporheic exchange flows in two small streams in the Cascade Mountains of Oregon, USA, Hydrolog. Process., 20, 267-287, 2006.

Zarnetske, J. P., Haggerty, R., Wondzell, S. M., and Baker, M. A.: Labile Dissolved Organic Carbon Supply Controls Hyporheic Denitrification, J. Geophys. Res., 116, G04036, doi:10.1029/2011JG001730, 2011a.

Zarnetske, J. P., Haggerty, R., Wondzell, S. M., and Baker, M. A.: Dynamics of nitrate production and removal as a function of residence time in the hyporheic zone, J. Geophys. Res., 116, G01025, doi:10.1029/2010JG001356, 2011b. 